Discussion Paper No. 15-068

\title{
How Can a Country 'Graduate' from Procyclical Fiscal Policy? Evidence from China
}

Clemens Fuest and Jing Xing

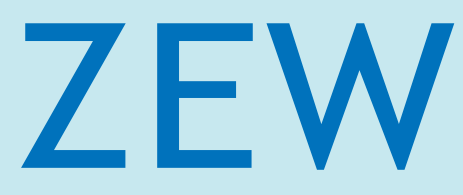

Zentrum für Europäische Wirtschaftsforschung $\mathrm{GmbH}$ Centre for European Economic Research 


\title{
Discussion Paper No. 15-068 \\ How Can a Country 'Graduate' from Procyclical Fiscal Policy? Evidence from China
}

\author{
Clemens Fuest and Jing Xing
}

Download this ZEW Discussion Paper from our ftp server:

http://ftp.zew.de/pub/zew-docs/dp/dp15068.pdf

Die Discussion Papers dienen einer möglichst schnellen Verbreitung von neueren Forschungsarbeiten des ZEW. Die Beiträge liegen in alleiniger Verantwortung der Autoren und stellen nicht notwendigerweise die Meinung des ZEW dar.

Discussion Papers are intended to make results of ZEW research promptly available to other economists in order to encourage discussion and suggestions for revisions. The authors are solely responsible for the contents which do not necessarily represent the opinion of the ZEW. 
How can a country 'graduate' from procyclical fiscal policy? Evidence from China

\author{
Clemens Fuest
}

ZEW and University of Mannheim

\author{
Jing Xing \\ Antai College of Economics and Management \\ Shanghai Jiao Tong University
}

\begin{abstract}
In this study, we analyze the cyclicality of fiscal policies in China during the period 1978-2013. We find that the cyclicality of local government spending in China significantly affects the cyclicality of total government spending. By employing both time-series and province-level panel data, we show that local budgetary government spending was strongly procyclical during the 1980s, but it became counter-cyclical with respect to nationwide output fluctuations and acyclical with respect to region-specific output shocks since the mid-1990s. We argue that these are likely to be consequences of the 1994 fiscal reform, which revamped the fiscal relations between the central and local governments, reduced the procyclicality of local government budgetary revenue and brought in counter-cyclical intergovernmental transfers. Findings of this study contribute to the debate on how developing and emerging countries, in particular those with federal fiscal structures, could reduce the procyclicality of their fiscal policies.
\end{abstract}

Key Words: Fiscal federalism, tax reform, government spending JEL Classification: H71, H72, H77 


\section{Introduction}

Macroeconomic stabilization is widely seen to be an important objective of fiscal policy. Achieving this stabilization requires spending to increase during economic downturns while taxes revenues should decrease, and vice versa. To some extent this happens automatically. For instance, if jobs are lost in an economic downturn, income tax revenue declines and expenditure on unemployment benefits increases. This automatic stabilization effect should be complemented by anticyclical discretionary fiscal policy measures. Observed fiscal policy, however, is often procyclical, undermining the effect of automatic stabilizers. The cost of procyclical fiscal policy is high, not just in terms of a loss in stability but also in the form of lower economic growth (Aghion and Marinescu, 2007).

In the literature, the procyclicality of fiscal policy is seen to be most pronounced in developing or emerging economies (Gavin and Perotti 1997; Talvi and Végh, 2005; and Ilzetzki and Végh, 2008, Frenkel et al. 2013). This phenomenon is usually linked to the lack of access to international credit markets (Gavin and Perotti, 1997) and poor institutions (Alesina and Tabellini, 2008). In the developed world, the issue of procyclical fiscal policy is seen to be most relevant in federations, especially for government spending at the sub-national level (Abbott and Jones, 2012; Clemens and Miran, 2012; and Rodden and Wibbels, 2010). ${ }^{1}$ Similar to the case of developing countries, procyclical fiscal policy at the sub-national level is often explained by limited access of local governments to the credit market. It is also explained by institutional restrictions such as balanced budget requirements or insufficient counter-cyclical intergovernmental transfers. ${ }^{2}$

China is both an emerging economy and a country with highly decentralized public spending. It is also viewed by various authors as a country with quasi federal structures (Qian and Weingast, 1997; Roland, 1999). Yet we argue in this paper that sub-national spending in China since the mid-1990s is perhaps an exception to the usual pattern of procyclical fiscal policy at the sub-national level. We argue that this is likely to be a consequence of the 1994 reform of the fiscal system in China. While sub-national spending was strongly procyclical before 1994, this pattern changed after the reform. Yet this does not mean that there is no room for improvement: while sub-national spending in China is countercyclical with regard to nationwide business cycles since 1994, it is rather acyclical with respect to local cycles.

\footnotetext{
${ }^{1}$ For example, Rodden and Wibbels (2010) argue that 'Subnational finance in several of the world's most decentralized federations is overwhelmingly pro-cyclical.’ (p. 59.).

${ }^{2}$ According to the normative theory of fiscal federalism (Musgrave 1959, Oates 1972, 1999), active fiscal stabilisation policies are a task of the central government, not of subcentral governments. This is because stabilisation policies of regional or local governments will lead to spillovers, so that individual jurisdictions have few incentives to engage in these policies. But this does not imply that fiscal policies of subcentral governments should be procyclical.
} 
Using both aggregate time series and provincial panel data during the period 1978-2013, we find that: 1) the cyclicality of provincial government spending in China significantly affects the cyclicality of overall government spending; 2) provincial government spending in China was highly procyclical before the 1994 fiscal reform but the degree of procyclicality is substantially reduced post the reform; 3)provincial government revenue became less procyclical after 1994; 4) provinces where value added taxes were used more intensively had less procyclical revenue and 5) the intergovernmental transfer system in China helps reduce the procyclicality of provincial government spending, in particular with respect to nationwide output fluctuations.

The contribution of our study to the literature is as follows. Frankel et al. (2013) find that about a third of the developing world has been able to 'graduate' from procyclical fiscal policies since the 1960s. These authors emphasize the role of institutions, such as the depth of financial integration and political checks and balances, in reducing the procyclicality of fiscal policies in developing countries. Earlier studies come to similar conclusions (Gavin and Perotti, 1997, Alesina and Tabellini, 2008). Our case study of China provides new perspectives on how countries, especially developing countries, could graduate from procyclical fiscal policies. First and foremost, our case analysis of China highlights the important role of the fiscal relations between the central and local governments in affecting the cyclicality of fiscal policies in any fiscal federations. To achieve anti-cyclical fiscal policies in fiscal federations, it is therefore crucial to take into account the incentives for different levels of governments and the behavior interactions between them.

Second, we find that tax revenue structures play an important role in the cyclicality of fiscal policies. One significant change in the tax revenue structures brought by the 1994 fiscal reform in China is the introduction of the value-added tax as an important source of tax revenue. ${ }^{3}$ We find that provinces where the value-added tax became a more important source of tax revenue post 1994 also experienced a more substantial reduction in the procyclicality of tax revenue, consistent with the hypothesis that the value-added tax provides a more stable tax base than direct taxes.

Third, our analysis of the Chinese experiences highlights the role of intergovernmental transfers in changing the cyclicality of local government spending in fiscal federations. While previous studies find that intergovernmental transfers are often procyclical so that they exacerbate the procyclicality of local government spending (Abbott and Jones, 2012; Blöchliger and Égert, 2013), we show that intergovernmental transfers and grants in China since 1994 are strongly

\footnotetext{
3 The concept of the value-added tax was first brought to China in the mid-1980s. However, before 1994 the value-added tax in China was restricted to a few products in a few manufacturing industries. It was not until the 1994 fiscal reform that the value-added tax is applied to a wide range of industries and became an importance tax revenue source for the government. Local governments were only able to maintain a share of the value-added taxes since the 1994 fiscal reform (Gordon and Li, 2013).
} 
countercyclical with respect to nationwide output shocks and weakly counter-cyclical towards region-specific output shocks. As intergovernmental transfers play a crucial role in financing local government after 1994, the transfer system helps reduce the procyclicality of local and total government spending.

The rest of the paper is organized as follows. In Section 2, we discuss the series of fiscal reforms in China since 1978, with a focus on the tax revenue sharing reform in 1994. In Section 3, we use time-series data to analyze the cyclicality of government spending in China during 1979-2013. In Section 4, we analyze the cyclicality of provincial government spending before and after the 1994 fiscal reform using provincial panel data. In Section 5, we discuss the role of the value-added taxes. We also discuss whether intergovernmental transfers in China are sufficient to smooth region-specific output shocks. Section 6 concludes.

\section{Stylized facts and policy background}

\subsection{Cyclicality of government spending in China: an overview}

The Chinese economy has been growing at a phenomenal rate since the opening-up policy in 1978. Nevertheless, as Brandt and Zhu (2000) point out, the Chinese economy also exhibited a marked cyclical pattern. Figure 1 illustrates the time-series evolution of the growth rates of real total government budgetary spending and real GDP in China since 1979. We observe a strong co-movement of the two growth rates before 1994, suggesting total government spending during this period was likely to be procyclical. This pattern, however, is less pronounced since 1994. In fact, these two growth rates moved in opposite directions in most years after 1994, notably during the mid to late 1990s and since the global financial crisis in 2008.

The GDP growth rate for the whole country, nevertheless, hides much variation in the growth experiences across regions. China has 27 provinces and 4 municipalities, each with distinct economic, geographic and demographic characteristics. Even though all regions enjoyed economic growth since 1978, the growth experience is not homogeneous. In Figure 2, the red line is the unweighted average real output growth rate across the 30 provinces and municipalities from 1979 to $2013 .{ }^{4}$ The blue bar is the 95\% confidence interval for the real output growth rate in each year. Figure 2 immediately reveals two messages. First, the post-1978 growth experience is uneven across regions in China as the $95 \%$ confidence intervals are widely spread in most years. Second, since the mid-1990s, there seems to be a convergence in terms of the growth rate of real output across regions over time as the blue bars became narrower during this later period.

Figures 1 and 2 together suggest notable changes in both the cyclical pattern of total government spending and regional variation of real output growth in China since the

\footnotetext{
${ }^{4}$ We exclude Tibet from this analysis to be consistent with empirical estimations in this study.
} 
mid-1990s. What can explain such pronounced changes? To answer this question, we will discuss the relevant policy background during this period in Section 2.2.

\section{Figure 1: Total budgetary government spending and GDP growth}

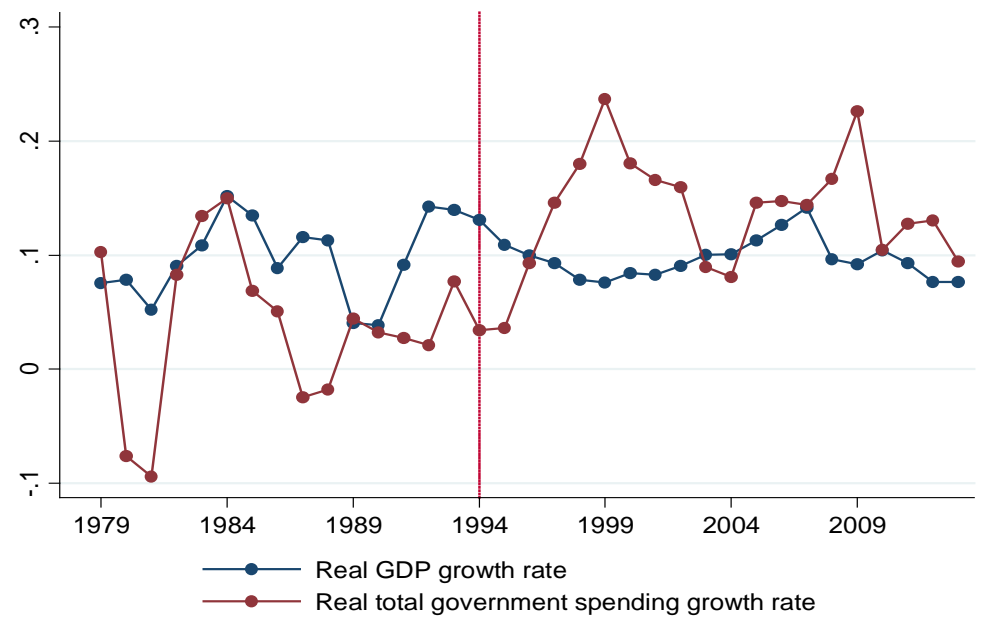

Figure 2: Regional variation in real GDP growth

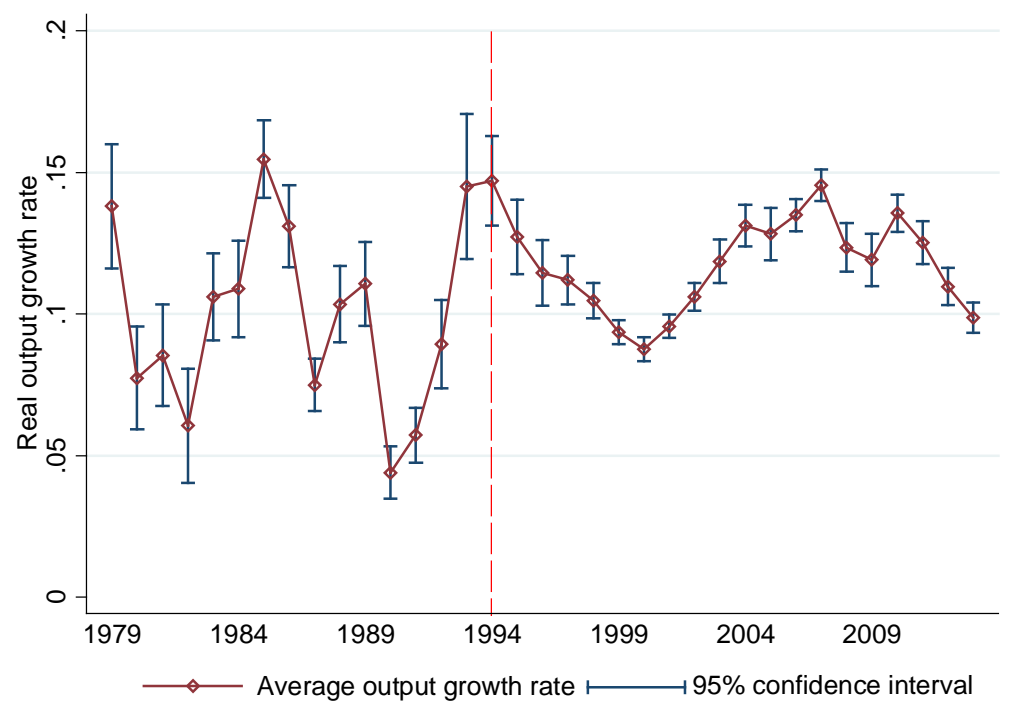

\subsection{The 1994 fiscal reform}

Since the reform and opening-up of the economy in 1978, China has gone through a series of fiscal reforms. The period between 1978 and 1994 could be described as a period of "fiscal decentralization" (Wong et al., 1993; Qian and Weingast, 1997). ${ }^{5}$ Starting from the mid-1980s, a fiscal contracting system between central and

\footnotetext{
${ }^{5}$ Zhang and Zou (1998) point out that decentralization in China during this period is a more accurate description for budgetary than extra-budgetary government spending, and there are considerable variations across provinces in terms of the degree of budgetary decentralization.
} 
provincial governments was implemented. ${ }^{6}$ During this period, a provincial government usually contracted with the central government on the total amount of tax revenue to be remitted to the central government. Once the agreed "quota" was met, the provincial government could keep the rest (Bahl and Wallich, 1992; Oi, 1992; Montinola, Qian, and Weingast, 1997). The total amount to be remitted from the provinces to the central government was often set ad hoc and usually lasted for 3-5 years. ${ }^{7}$

Fiscal decentralization during the early economic reform period is believed to have provided strong incentives for provincial governments to develop their economy (Oi, 1992; Blanchard and Shleifer, 2000; and Jin, Qian, and Weingast, 2005). Nevertheless, this system also created incentive distortions. For example, provincial governments now had the incentives to avoid remittance to the central government by means such as growing their off-budgetary accounts (Oi, 1992). Together with the declining profits of state-owned enterprises during this period ${ }^{8}$, such reaction of the local governments to the fiscal contracting system led to a dramatic decline in two ratios: the ratio of total government revenue to GDP, and the ratio of central government revenue to total government revenue. As shown in Figure 3, the percentage of central government revenue in total government revenue increased initially during the early 1980s but declined from around 40\% in the mid-1980s to around 20\% in 1993.

The fiscal contracting system implemented in the 1980s may also have introduced a procyclical bias to the fiscal system (Bahl and Wallich, 1992). As provincial governments only needed to remit a more or less constant level of revenue to the central government in most cases, revenue realized by provincial governments tended to increase rapidly with economic growth. Consequently, provincial government spending also tended to increase substantially in a booming year, given the balanced budget requirement. In contrast, central government revenue tended to be more stable regardless of the underlying economic growth.

In 1994, the Chinese government carried out a significant fiscal reform which replaced the fiscal contracting system implemented in the 1980s by a new tax revenue-sharing system. The 1994 fiscal reform aimed to address the fiscal decline of the central government and to revamp the old central-local fiscal relations (Wong, 2000). As well documented in existing studies, the 1994 fiscal reform changed the fiscal relations between the central and the provincial governments in many aspects.

Firstly, the reform set formal rules for allocating tax revenue between central and

\footnotetext{
6 In the rest of the paper, we will use "provincial” government and "local” government interchangeably.

${ }^{7}$ Oi (1992) and Balh and Wallich (1992) provide detailed explanations for this sharing system during the 1980 s.

${ }^{8}$ Taxation on the state-owned enterprises was the most important source of revenue for the central government during this 1980s.
} 
provincial governments that applied to all provinces. There are tax revenues wholly owned by the central government, tax revenues wholly owned by the provincial government, and others shared between the central and the provincial government. Instead of remitting a fixed level of tax revenue to the central government, now the central government could share a fixed percentage of certain types of tax revenues. ${ }^{9}$ Consequently, as shown in Figure 3, the 1994 fiscal reform significantly strengthened the fiscal capacity of the central government. The ratio of central government budgetary revenue in total government budgetary revenue jumped from 22\% in 1993 to $55.7 \%$ in 1994 and it remains at around 50\% ever since. In contrast, as Figure 4 reveals, there is a gradual process of decentralization on the expenditure side since the early 1980s. Strikingly, by 2013 only around 15\% of total budgetary spending was conducted by the central government, which makes China probably one of the most decentralized countries in the world in terms of government spending. ${ }^{10}$

Figure 3: Central government revenue (\% of total government revenue, 1978-2013)

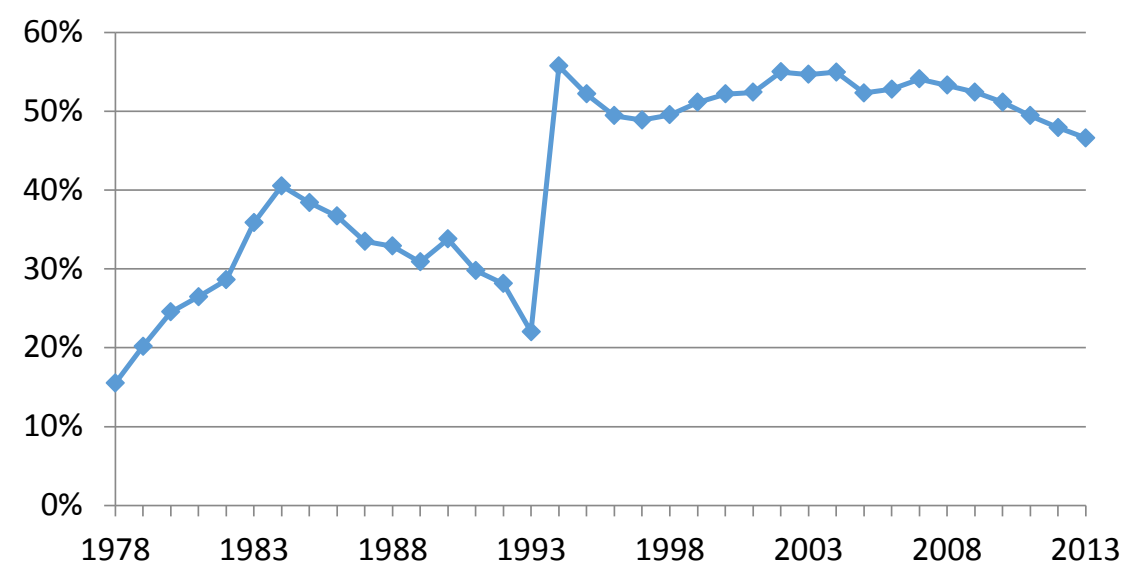

\footnotetext{
${ }^{9}$ Appendix A reports the categories of taxes and the associated revenue sharing rules between the central and the provincial government.

${ }^{10}$ This is not the same regarding government tax revenue as both tax rates and tax bases are set by the central government.
} 
Figure 4: Central government expenditure (\% of total government expenditure, 1978-2013)

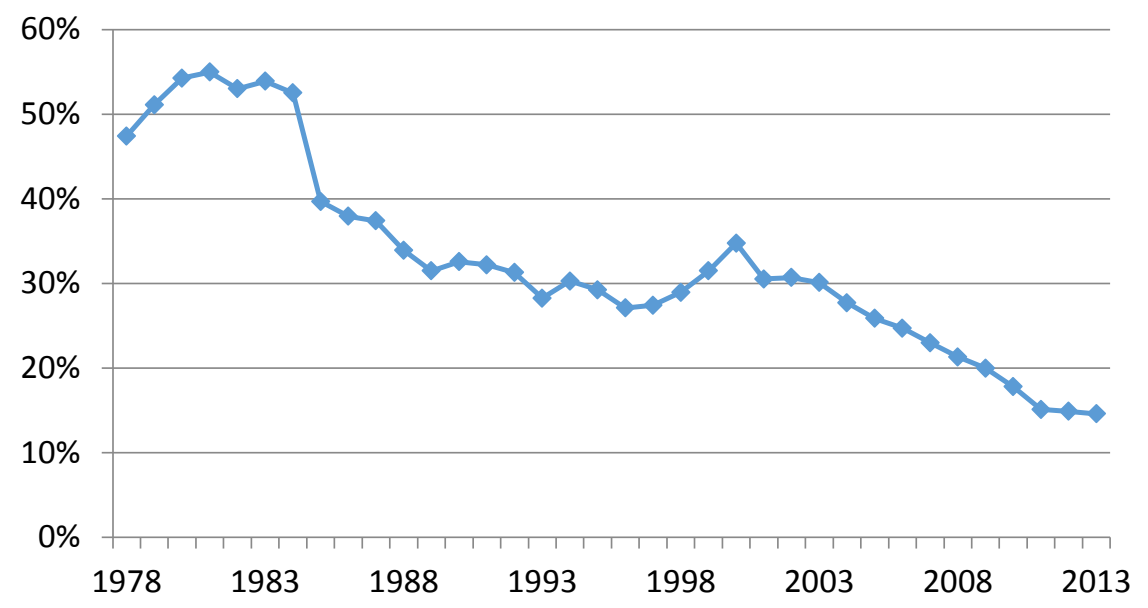

Re-centralization of revenue combined with decentralization of expenditure implies fiscal imbalances across the different tiers of government. Figure 5 illustrates the evolution of the average provincial government fiscal gap, defined as (Expenditure-Revenue)/Expenditure, during the period 1978-2013. ${ }^{11}$ It shows that provincial governments ran a surplus during the early 1980s and more or less maintained a fiscal balance in the late 1980s and early 1990s. However, after 1994 provincial tax revenue could only finance around $40 \%-50 \%$ of local expenditures, suggesting that a substantial proportion of local spending had to be financed by other sources.

Figure 5: Local government fiscal gap 1978-2013

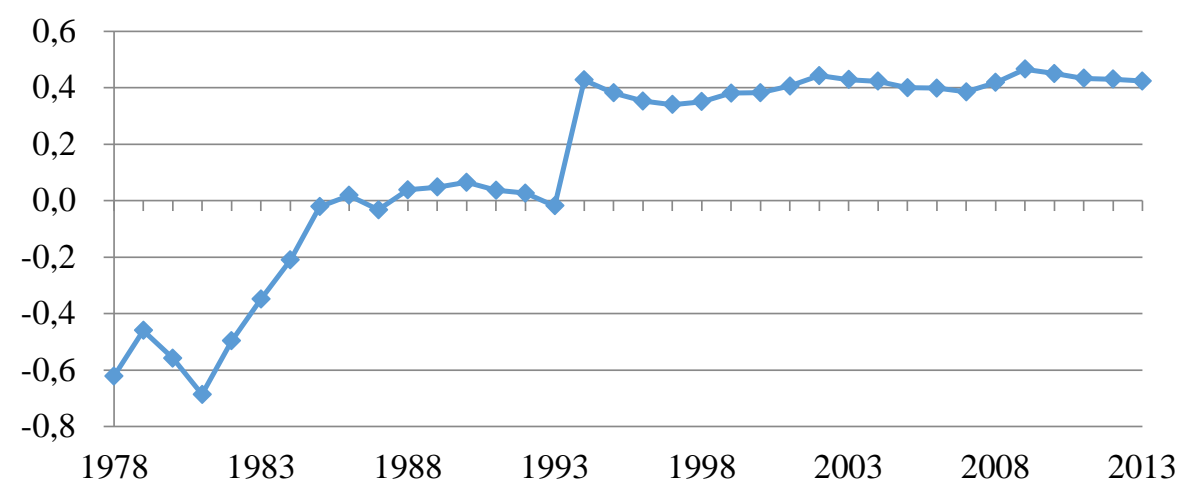

Secondly, the 1994 fiscal reform expanded the value-added tax to cover all manufacturing industries and it became an important source of revenue for the Chinese government since then. Although VAT was collected before 1994, the nature of the pre-1994 VAT was different from that of VAT implemented since 1994. Regardless of this difference, Figure 6 indicates that the VAT generated less than $10 \%$ of total tax revenue for the total government in 1985.This share increased to around

\footnotetext{
${ }^{11}$ We calculate the fiscal gap for each province in each year and then average this ratio across provinces to construct the time-series in Figure 5.
} 
$20 \%$ by 1993 . VAT revenue increased to around $45 \%$ of total tax revenue for total government in 1994. Since then its share has declined slightly but it remains an important revenue source.

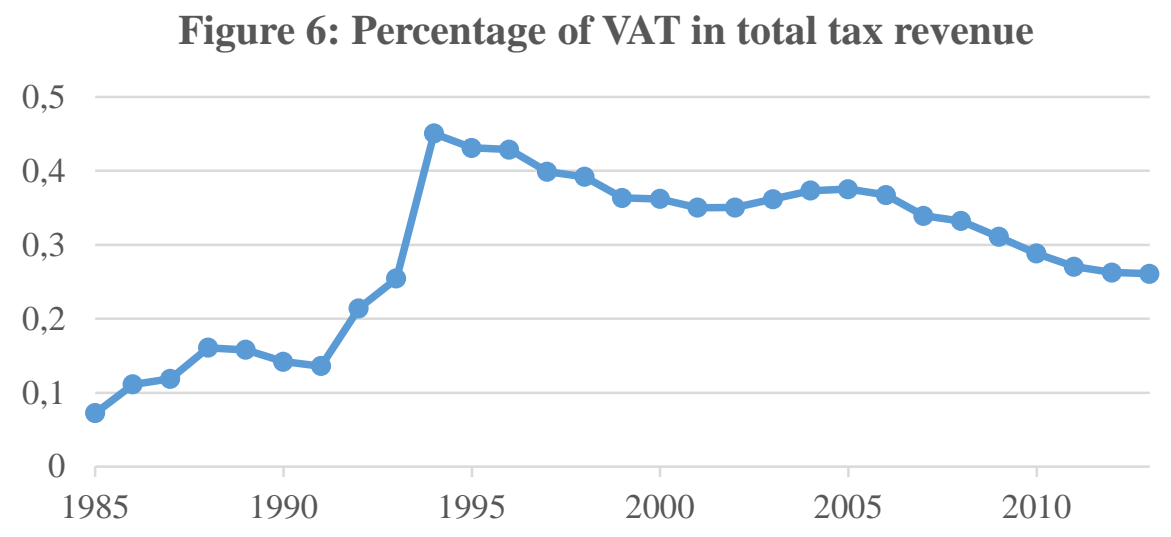

Thirdly, intergovernmental transfers and grants became a key instrument to finance provincial government spending after the 1994 fiscal reform. Figure 5 indicates that around 40-50 percent of provincial government expenditure needed to be financed by sources other than local tax revenue, and the majority of these non-tax sources of funds are in the form of transfers and grants from the central government since 1994. Although they existed well before 1994, intergovernmental transfers and grants played a much less important role in provincial government budgetary spending then, which is perhaps not surprising given the much deprived fiscal capacity of the central government during the 1980s. Since 1994, the role of intergovernmental transfers is particularly important for Chinese local government, considering that provinces and municipalities cannot independently issue debt to finance their investment. ${ }^{12}$

Intergovernmental transfers and grants take three different forms in China: general transfers, earmarked transfers, and tax rebates. General transfers are mainly used to reduce fiscal disparities across provinces and to ensure equal access to basic public services in each region. A further breakdown of data suggests that around $35-40 \%$ of general transfers come in the form of fiscal equalization payments. Wang and Herd (2013) provide the formula for fiscal equalization in China, which depends on: 1) the gap between the standardized expenditure and revenue for each province; ${ }^{13}$ 2) the

\footnotetext{
${ }^{12}$ Very recently this restriction was relaxed for a few selected cities. Nevertheless, local government can effectively borrow to finance its budgetary spending via the central government, but only a small percentage of local expenditure is financed in this way. Local government also borrows via channels such as a Local Government Financing Vehicle (LGFV), but borrowing via the LGFVs is mainly to finance off-budgetary infrastructure investment (see, Zhang and Barnett, 2014).

${ }^{13}$ Standardized spending is the sum of total standardized spending for 14 sectors. For each sector, the standard national average standard expenditure per registered inhabitant is calculated. The national average is then converted to a provincial average by adjusting for cost differences caused by the difference from the national average of altitude, population density, temperature, transport distances, the number of civil servants, regional wage differentials, number of students and the prevalence of minority groups. The cost factors vary according to the spending category. Total standardized spending was calculated as the product of standardized spending per registered inhabitant and the number of
} 
gap between the actual expenditure and revenue for each province; 3) and the total equalization grant available in the budget year. Earmarked transfers are used to subsidize local projects in certain areas subject to matching outlays by local government. Tax rebates are tax revenues given back by the central-government to provinces based on rules set after 1994 to compensate local government for the loss of tax revenue due to the reform. Tax rebates and earmarked transfers were more important forms of intergovernmental transfers immediately after the 1994 fiscal reform. In more recent years the central government has been trying to increase the relative importance of general transfers. With available information at the provincial level, we calculate that tax rebates were about $10 \%$ of total transfers, and the figures are $50 \%$ and $40 \%$ for general purpose transfers and earmarked transfers respectively in the year 2013.

We obtain time series data for the share of earmarked transfers in total balance revenue at the prefecture level during the period 1996-2009. ${ }^{14}$ More specifically, we aggregate the earmarked transfers and total balance revenue across prefectures within each province, and then divide the sum of earmarked transfers by the sum of total balance revenue for each province in each year. We then plot the averages and the standard deviations of this ratio across provinces in Figure 7 during 1996-2009. We only analyze the earmarked transfers as data is often missing for tax rebates and general purpose transfers. Figure 7 shows a general upward trend in the percentage of earmarked transfers in total balance revenue during this period, although there are considerable variations across provinces. It is also worth mentioning that although certain types of earmarked transfers require matching from the provincial governments, the way of matching is usually determined by the central government in China. Even though the way of matching is likely to be subject to bargaining between the central and provincial governments, provincial governments probably have much less power in this bargaining process.

registered inhabitants. For each type of tax, standard tax revenue is determined by multiplying the standard tax base with the standard tax rate (Wang and Herd, 2013).

${ }^{14}$ Here, total balance revenue refers to the sum of tax rebates, general purpose transfers, earmarked transfers, and loans from national debt. We do not have similar time-series data the provincial level. Overall revenue at the prefecture level is total balance revenue plus budgetary revenue. The latter includes all tax revenue. As breakdowns of transfers are not available at the province level but available at the prefecture level, we use aggregate earmarked transfers across prefectures as an approximation to the total amount of earmarked transfers a province receives. 
Figure 7: The ratio of earmarked transfers to total balance revenue 1996-2009

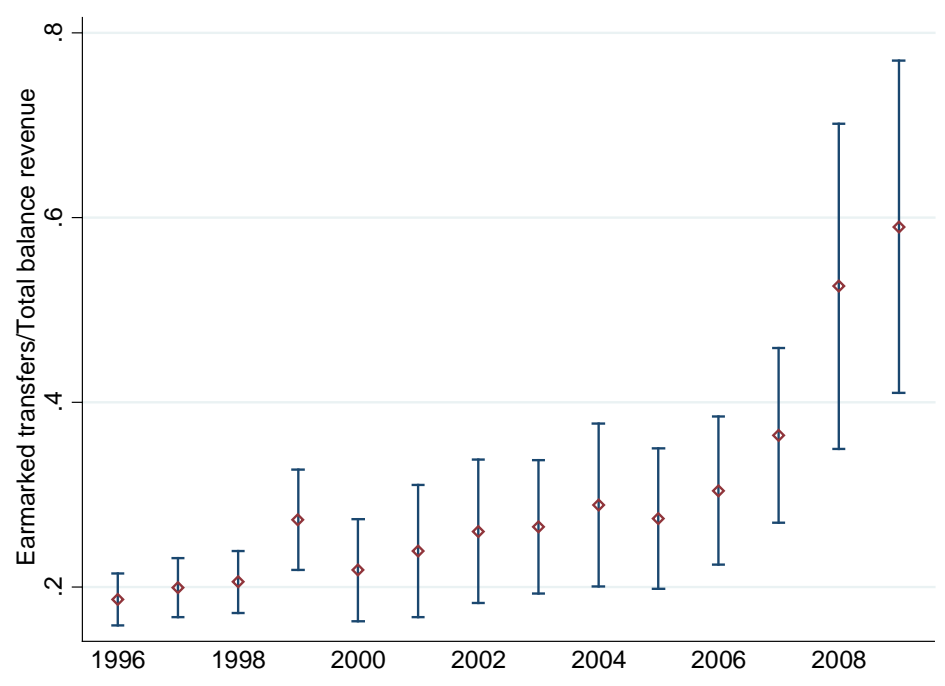

It is worth noting that although we focus on the budgetary account in this study, there are three different types of accounts at each level of Chinese government: the budgetary account, the government-managed fund, and the extra-budgetary account. ${ }^{15}$ Intergovernmental transfers are more important to the budgetary account than to the other two. Data is difficult to gather in particular regarding the government-managed fund. Take the year 2010 for example when data is available, the figures from the three accounts for local government expenditures (aggregated over provinces) are: $7,388,3,167$, and 536.8 billion RMB, respectively. This implies $66 \%$ of the local expenditure comes from the budgetary account, $28 \%$ from the government-managed fund, and 6\% from the extra-budgetary account. In 2010, 44\% of total local budgetary expenditure was financed by transfers from the central government. In contrast, only around $15 \%$ of expenditure from the local government-managed fund is financed by central government transfers. Extra-budgetary accounts do not involve central-provincial transfers as they are left to each province alone.

To summarize, the 1994 fiscal reform significantly changed the central-local government fiscal relations in China as discussed in this section. Despite a large body of studies on the consequences of the 1994 fiscal reform, it is somewhat surprising that little has been said about its impact on the cyclicality of fiscal policies. We observe in Figure 1 that total government spending seems to be less procyclical since the mid-1990s, which coincides with the fiscal reform. This leads to our hypothesis that the 1994 fiscal reform reduced the procyclicality of government spending. In particular, the replacement of the fiscal contracting system by the revenue sharing

\footnotetext{
${ }^{15}$ There is no clear distinction between capital account and operating account in China. For example, infrastructure investment could be included in all three accounts. On the revenue side, all tax revenues go into the budgetary account.
} 
system, the adjustment of the tax revenue structures, and the increasing importance of the intergovernmental transfers and grants for local government financing could be the underlying factors that helped reduce the procyclicality of fiscal policies.

\section{Cyclicality of government spending: time-series analysis}

In this section, we analyze the cyclicality of government spending using aggregate time-series data. Although estimations based on short time series may produce inaccurate results, one advantage of conducting the time-series analysis is that we can directly investigate whether the cyclicality of local government spending affects the cyclicality of overall government spending. To measure the cyclicality of government spending, we follow the specification in Lane (2005) and estimate Equation $1:^{16}$

$$
\text { (1) } \Delta \ln E X P_{t}=\alpha+\beta \Delta \ln G D P_{t}+\varepsilon_{i, t}
$$

In Equation 1, the dependent variable is the first-difference of the natural logarithm of real government expenditures, and the explanatory variable is the first-difference of the natural logarithm of real GDP. We obtain nominal government expenditure and nominal GDP for the period 1978-2013 from the China Statistics Yearbooks. ${ }^{17}$ We use the GDP deflator, provided by the World Bank, to convert these nominal time-series into real terms. Detailed variable definitions and data sources are provided in Appendix B. We estimate Equation 1 controlling for heteroskedasticity in the error term. $^{18}$

Taking the whole period 1978-2013 together, Table 1 indicates that total government expenditure in China during this period is procyclical. ${ }^{19}$ The estimated coefficient $\beta$ is around 0.40 , although it is associated with a large standard error. In contrast, the estimated $\beta$ regarding central government spending is negative and with a magnitude of around -0.86. Interestingly, local government spending is highly procyclical--the estimated $\beta$ is around 1.25 and is statistically significant. These estimates show that the procyclicality of local government spending tends to offset the counter-cyclicality of central government spending, which is not surprising given that expenditure is highly decentralized in China.

\footnotetext{
${ }^{16}$ One alternative method is to regress the cyclical component of government spending on the cyclical component of GDP. The cyclical components of these variables can be obtained by applying filters such as the Hodrick-Prescott (HP) filter. We obtain similar results when using this alternative strategy.

${ }^{17}$ Government spending does not include net lending. However, this figure contains interest payment on domestic debt since 2002. We do not adjust the spending figures for interest payment because we do not have this information for local and central government. In a separate exercise, we obtain figures for interest payment on domestic debt for total government from the China Fiscal Yearbooks and adjust the total government spending series from 2002 accordingly. The growth rates of real total government spending based on the unadjusted and the adjusted data, however, are almost identical.

${ }^{18}$ In separate exercises, we also control for serial correlations in the error term and the results are not much affected.

${ }^{19}$ We exclude the year 1994 from the regression analysis as there were substantial changes in the growth rate of government expenditure and revenue in this year due to the fiscal reform. Including the year 1994 will hence bias our estimation results.
} 
We obtain more interesting results once we split the whole sample period into two sub-samples, the period before the 1994 reform, and the post-1994 period. First, we find that total government spending in China before 1994 was pro-cyclical, which was mainly driven by the strong procyclicality of local government spending during this period. In contrast, after 1994, total government spending became counter-cyclical. On the one hand, central government spending became somehow more counter-cyclical post the reform. On the other hand and perhaps more importantly, local government spending was highly procyclical before the reform but became acyclical or weakly counter-cyclical post the reform. ${ }^{20}$

Can the observed changes in the cyclicality of government spending before and after the 1994 fiscal reform be explained by changes in the cyclicality of government revenue? To investigate this possibility, we replace real government expenditure with real government revenue on the left-hand side of Equation 1.The estimation results are summarized in the last three columns of Table 1. Unsurprisingly, total government revenue is procyclical as tax bases move in the same direction as output. Central government revenue growth is negatively correlated with GDP growth before 1994 . This puzzling result could be explained by the deterioration of profits of state-owned enterprises during this period that contributed to the declining central government revenue. It could also be explained by the fact that local governments attempted to avoid remittance to the central government during the decentralization period, despite the phenomenal economic growth. In fact, as the central government gained a much stronger fiscal position after the 1994 fiscal reform, we observe its revenue to move in the same direction with GDP as it should be. Local government revenue was highly procyclical both before and after the 1994 reform. Although the magnitude of the estimated revenue elasticity with respect to GDP is smaller for the post-reform period, the change is not statistically significant. Therefore, based on these time-series estimations, there is no strong evidence that changes on the revenue side have led to the reduced procyclicality of local government spending. ${ }^{21}$

To test formally whether the change in the cyclicality of government spending before and after the 1994 fiscal reform is statistically significant, we estimate Equation 2 as below:

(2) $\Delta \ln E X P_{t}=$ constant $+\alpha_{0} \Delta \ln G D P_{t}+\alpha_{1} P O S T+\alpha_{2} P O S T \times \Delta \ln G D P_{t}+\varepsilon_{i, t}$

\footnotetext{
${ }^{20}$ It is worth noting that in their cross-country study on graduation from fiscal pro-cyclicality, Frankel et al. (2013) classified China as "still in school". Using the GFS data provided by the International Monetary Fund, they find a positive correlation between the cyclical component of government spending and that of the real GDP during the period 2000-2009. However, the government spending figures in their study include general government net lending, which is not included in the government spending figures we use. In a separate exercise using the GFS data, we find that general government net lending in China is procyclical during 2000-2009 but budgetary spending is not, which suggests their conclusion is likely driven by the procyclicality of government net lending.

${ }^{21}$ As we will show later, there is much stronger evidence that local government revenue became less procyclical after 1994 when we use provincial panel data and control for region-specific time trends.
} 
where POST is a dummy variable that equals 1 after the 1994 fiscal reform, and 0 otherwise. In Columns 1-3, we estimate Equation 2 without additional control variables. In Columns 4-6, we control for the percentage change of trade openness and total government deficit (with a one-year lag) as in Alesina and Tabellini (2008).Trade openness is defined as the sum of exports and imports divided by GDP. Total government deficit is defined as (Total government expenditure-Total government revenue)/GDP. The patterns are similar with or without these additional control variables. Table 2 reveals that both total government and local government spending became less procyclical post the 1994 fiscal reform, and the change, as captured by $\alpha_{2}$, is statistically significant. Central government spending became somewhat more counter-cyclical post the 1994 reform, but not as significantly as for local government spending.

\section{Analysis based on provincial panel data}

\subsection{Cyclicality of local government spending: benchmark results}

To further investigate the cyclicality of local government spending, we now turn to provincial panel data during the period $1978-2013 .^{22}$ The analysis based on aggregate time-series data provides us with an overview regarding the cyclicality of local government spending with respect to the nationwide business cycles (or symmetric output shocks). However, it is not clear whether local government spending would respond to local or nationwide business cycles. This highlights one limitation of the time-series analysis. With provincial level panel data, we are able to distinguish between region-specific output fluctuations (asymmetric shocks) and nationwide fluctuations (symmetric shocks). Specifically, we estimate the cyclicality of Chinese provincial government spending with respect to both province-specific and nationwide output fluctuations based on Equation $3:^{23}$

$$
\text { (3) } \Delta \ln E X P_{i, t}=\alpha_{0}+\alpha_{1}\left[\Delta \ln G S P_{i, t}-\Delta \ln G D P_{t}\right]+\alpha_{2} \Delta \ln G D P_{t}+v_{i}+\gamma \mu_{t}+\varepsilon_{i, t}
$$

where $E X P_{i, t}$ and $G S P_{i, t}$ are the real government budgetary expenditure and real output in province i in year t, respectively. $v_{i}$ is the province-specific fixed effect, and $\mu_{t}$ is the time effect. Provincial nominal government expenditures and output data are obtained from the China Fiscal Statistics Yearbooks. To transform the nominal expenditure and output data into real terms, we use province-specific output deflators. ${ }^{24}$ In Equation 3, $\alpha_{1}$ captures the elasticity of provincial government spending towards province-specific output shocks, while $\alpha_{2}$ captures the elasticity of

\footnotetext{
${ }^{22}$ We exclude Tibet from our regression analysis as data for Tibet is missing for many years.

${ }^{23}$ In Appendix C, we investigate the time-series properties of local government expenditures, revenues, and net transfers. We find that the levels of these variables are likely to be non-stationary but the first-differences of these variables are all stationary.

${ }^{24}$ The results are very similar when we use national GDP deflator as the common deflator for all provinces.
} 
provincial government spending towards nationwide shocks.

In Table 3, we report the sub-period estimations based on Equation 3 in Columns 1 and $2 .{ }^{25}$ In these two columns, we do not control for the time effect. First, we find that provincial government spending in China was strongly procyclical with respect to both province-specific and nationwide output fluctuations prior to the 1994 fiscal reform. However, local government spending became less procyclical with respect to local business cycles, and became acyclical towards nationwide GDP fluctuation after 1994. In Column 3, we test whether the estimated cyclicality of provincial government spending before and after 1994 is statistically different. To do so, we interact the dummy variable POST with $\Delta \ln G S P_{i, t}$ and $\Delta \ln G D P_{t}$. We include these two interaction terms together with the dummy variable itself as additional explanatory variables in Equation 3. We report the estimation result using the full sample (excluding the year 1994) in Column 3. The result indicates that local government spending became significantly less procyclical with respect to both asymmetric and symmetric shocks after 1994.

In Columns 4-6, we repeat the estimations as in Columns 1-3 but controlling for a common linear time trend. ${ }^{26}$ We further control for province-specific linear trends in Columns 7-9. The results in these alternative specifications remain similar to those in Columns 1-3.

\subsection{Cyclicality of local government revenue}

Could the changes in the cyclicality of local government spending be explained by changes on the revenue side? Table 4 reports the estimated cyclicality of provincial government revenue before and after the 1994 fiscal reform, using specifications similar to those in Table 3.More specifically, we replace $\Delta \ln R E V_{i, t}$ as the dependent variable in Equation 3, and estimate it without any linear trend, with a common linear trend, or with province-specific linear trends.

Table 4 suggests that post the 1994 reform, local government revenue became less procyclical with respect to both local and nationwide output fluctuations. The reduction in the estimated revenue elasticity with respect to output is most substantial when we control for province-specific linear trends (Columns 6-9). It is worth noting that even in these specifications, local government revenue remains procyclical with respect to output as they should be. Mechanically, a reduction in local government revenue procyclicality would translate into less procyclical local government spending after 1994, if everything else is unchanged.

\footnotetext{
${ }^{25}$ We test the time-series properties of relevant variables in Appendix C.

${ }^{26}$ We include two linear trends in Column 6 to capture potential structure breaks. Provincial-specific trends are included in separate exercises and similar results are found.
} 


\subsection{The role of intergovernmental transfers}

In a fiscal federation, central government can affect the cyclicality of local government spending via the intergovernmental transfer system. Previous studies find somewhat mixed evidence for whether intergovernmental transfers attenuate or amplify the procyclicality of sub-national government spending. For example, Sorenson, Wu, and Yosha (2001) find that intergovernmental grants in the United States are counter-cyclical with respect to state-specific business cycles. However, they find grants to be more generous during US nationwide upturns. Arena and Revilla (2009) find that intergovernmental transfers in Brazil are acyclical with respect to state-specific shocks but similar to Sorenson, Wu, and Yosha (2001), they find transfers in Brazil to be procyclical with respect to nationwide business cycles. Other studies which do not explicitly control for nationwide output shocks (Rodden and Wibbels, 2010; Végh and Vuletin, 2013; Blöchliger and Égert, 2013; and Seitz, 2000) find intergovernmental transfers and grants to be procyclical with respect to region-specific shocks, although these results may be biased due to the omission of the nationwide output shocks (Sorenson, Wu, and Yosha, 2001).

Intergovernmental transfers could be procyclical in reality for many reasons. For example, if the intergovernmental transfers take the form of matching grant, they would be procyclical as local government spending itself is often procyclical. Procyclical intergovernmental transfers can also occur if there is some arrangement about tax revenue sharing, as tax revenue tends to be highly procyclical. Fiscal equalization transfers could be destabilizing for poorer local governments if grant levels are determined by the difference between a local government's fiscal capacity and the national average as in Germany, for instance (Bargain et al., 2013). In such a system, if the economy is hit by a symmetric shock, net recipients in the system could suffer from declines in both their own revenue and transfers from the equalization system. Political factors can also lead to procyclical transfers and grants as explained by Rodden and Wibbels (2010): as the central government is more willing to allocate money into areas where it can claim direct credit, it is less likely to increase transfers to local government during the downturns when the central government's own budget becomes tight.

Turning to the Chinese experience, we report in Table 5 the estimated cyclicality of real net transfers at the provincial level with respect to region-specific and nationwide output fluctuations. We collected nominal data for net transfers from the China Fiscal Statistics Yearbooks, which is only available from 1995 onwards. ${ }^{27}$ We then convert these nominal figures into real ones using province-specific output deflators. In Columns 1-3, we conduct estimations with different time effects. We find that net transfers are strongly counter-cyclical with respect to nationwide output

\footnotetext{
${ }^{27}$ Intergovernmental transfers and grants did exist before 1994, but they were much less important to local government financing then.
} 
fluctuations - the estimated coefficient on $\Delta \ln G D P_{t}$ is negative and statistically significant in all columns, and the magnitude of the point estimate (in absolute value) is large. There is much weaker evidence, however, that real net transfers are counter-cyclical with respect to province-specific shocks as the estimated coefficient on $\left[\Delta \ln G S P_{i, t}-\Delta \ln G D P_{t}\right]$ is negative but not statistically significant.

\subsection{Robustness checks}

Our estimation results so far suggest that local government spending in China became dramatically less procyclical after the 1994 fiscal reform, which could be explained by less procyclical revenue and counter-cyclical intergovernmental transfers. One potential issue with the econometric specifications as Equation 3 is that we do not control for potential co-integration between variables. For example, if there is a long-run equilibrium relation between output and expenditure, ignoring such co-integration relation and simply estimate Equation 3 may lead to biased estimates.

As a robustness check, we then estimate an error-correction model as Equation 4:

$$
\text { (4) } \begin{aligned}
\Delta \ln E X P_{i, t} & =\alpha_{0} \\
& +\alpha_{1}\left[\Delta \ln G S P_{i, t}-\Delta \ln G D P_{t}\right]+\alpha_{2} \Delta \ln G D P_{t}+\theta\left[\ln E X P_{i, t-1}\right. \\
& \left.-\beta_{1}\left(\ln G S P_{i, t-1}-\ln G D P_{i, t-1}\right)-\beta_{2} \ln G D P_{i, t-1}\right]+v_{i}+\gamma_{i} \mu_{t}+\varepsilon_{i, t}
\end{aligned}
$$

where $\beta_{1}$ and $\beta_{2}$ measure the long-run relations between government spending, provincial output (relative to the national GDP), and total GDP. If there exist co-integrated relations between these variables, the estimated $\beta_{1}$ and $\beta_{2}$ would be statistically different from zero. Moreover, $\theta$ measures the convergence speed of government spending towards the equilibrium level. $\alpha_{1}$ and $\alpha_{2}$ continue to capture the short-run dynamics. $\mu_{t}$ is a linear trend and we allow its coefficient to differ across provinces in some specifications.

We can estimate Equation 4 restricting all the parameters to be the same across provinces using the OLS estimator. Nevertheless, there is no reason to impose the same long-run and short-run dynamics on different provinces. As further robustness checks of our benchmark results, we estimate Equation 4 using the Pooled Mean-group and the unweighted Mean-group estimators (Pesaran, Shin, and Smith, 1999; Pesaran and Smith, 1995). The PMG estimator restricts the long-run parameters in Equation 4 ( $\beta_{1}$ and $\beta_{2}$ ) to be the same across provinces while allowing the short-run parameters $\left(\alpha_{1}\right.$ and $\alpha_{2}$ ) the speed of convergence $(\theta)$ to differ. ${ }^{28}$ The MG estimator, on the other hand, allows all the short-run and long-run parameters to differ across provinces, and calculated the unweighted averages of these estimated coefficients. The MG estimator is most flexible among all specifications, but coefficients yielded are likely to be associated with large standard errors as the length of our panel data is short.

${ }^{28}$ We report the unweighted average coefficients for these parameters. 
We estimate the short-run and long-run elasticities of local government spending, revenue, and intergovernmental transfers with respect to both local and national output fluctuations in Appendix D (Tables D.1-D.3). In all these tables, we allow for province-specific linear trends. The magnitude of the point estimates in these tables is sensitive to the estimators we use, but the general pattern of our benchmark results based on the pooled estimations remains unchanged. Focusing on the estimated short-run elasticities, we continue to find that both local government spending and revenue became less procyclical after the 1994 fiscal reform, and intergovernmental transfers are counter-cyclical with respect to nationwide output fluctuations.

\section{Discussion}

\subsection{Why has local revenue become less procyclical?}

\subsubsection{The effect of revenue structure changes}

We have observed that provincial government revenue became less procyclical after the 1994 fiscal reform, which could partly explain why provincial government spending in China also became less procyclical after 1994. The question is, what can explain the change in the estimated revenue elasticity?

One explanation, as already mentioned in Section 2.2, is that the procyclicality bias due to the old fiscal contracting system was corrected since the old system was overhauled and replaced by the new revenue-sharing system: provinces can now only keep a fixed proportion of revenue shared with the central government instead of keeping any surplus exceeding the fixed quota. Another possible explanation is linked to the value-added tax (VAT). Unlike corporate profits, the base of VAT is likely to be less volatile. Therefore, shifting tax revenue towards VAT may reduce revenue elasticity. Even though all provinces adopted VAT after the 1994 fiscal reform, the importance of VAT in total tax revenue varies considerably across provinces, probably due to their different economic structures. For example, the percentage of VAT in total tax revenue averaged between 1995 and 2013 is 10\% in Hainan and is 30\% in Shanxi. This heterogeneity allows us to investigate the role of VAT for revenue cyclicality. More specifically, we separate provinces into two groups depending on whether the ratio of VAT in total tax revenue averaged between 1995 and 2013 in a certain province is above or below the corresponding national median (20.3\%). We then estimate the elasticity of local government revenue based on Column 9 of Table 4 for the two groups in Columns 1-2 of Table 6, separately. We find that only provinces where VAT is used more intensively experienced significant reduction in the elasticity of revenue with respect to both local and national output fluctuations after the 1994 fiscal reform.

Alternatively, we calculate the average ratio of VAT in total tax revenue between 1995 
and 2013 for each province, and then interact this ratio with $\left[\Delta \ln G S P_{i, t}-\Delta \ln G D P_{i, t}\right]$ and $\Delta \ln G D P_{i, t}$, respectively. We then estimate the cyclicality of tax revenue post 1994 including these interaction terms. The result is reported in Column 3. The estimated coefficients on these additional interaction terms are negative, although only the estimated coefficient on the interaction with national GDP growth is statistically significant. The result provides further evidence that tax revenue became less procyclical, in particular with respect to the nationwide output fluctuations, if VAT is a more important source of tax revenue for the local government.

\subsubsection{The effect of privatization}

An alternative explanation for the reduced revenue procyclicality observed in the data is related to the privatization process of the state-owned enterprises (SOEs). There could be a link between privatization and the cyclicality of revenue for the following reason. Profits remittance and income taxes from the SOEs were the most important source of revenue for Chinese local government in the 1980s. Since the opening-up of the economy in 1978, however, SOEs suffered from losses and many had to rely on government subsidies. Government subsidies to loss-making SOEs are counted as negative revenue in the budgetary account, and this item is likely to be highly procyclical. $^{29}$ As the privatization process went on through the 1990s and early 2000s, many SOEs were shut down which may lead to a smaller percentage of government subsidies (in absolute values) in total budgetary revenue. Mechanically, this contributed to the reduction in the procyclicality of local revenue.

Nevertheless, if revenue became less procyclical because of privatization, we should not observe a structural change before and after the 1994 fiscal reform as privatization in China is a gradual process starting as early as in the 1980s. To test the effect of privatization, we construct two proxies. To capture the scale of privatization, we calculate employment in SOEs as a ratio in total employment for each province $\left(S O E_{-} E M P_{i, t}\right)$. During the sample period, the average $S O E_{-} E M P$ across provinces decreased from almost $100 \%$ in 1978 to around $88 \%$ in 1993 and to only around $18 \%$ in 2013. To test whether government subsidies to loss-making enterprises affect the elasticity of government revenue towards output fluctuations, we divide the number of loss-making enterprises by the total number of enterprises $\left(\operatorname{Loss}_{i, t}\right) .{ }^{30}$ We then include the first differences of these two ratios as additional explanatory variables when estimating the elasticity of government revenue towards output fluctuations. Table 7 reports the results. ${ }^{31}$

In Column 1, we include the first difference of the ratio of SOE employment in total

\footnotetext{
${ }^{29}$ This is to say that government subsidies to the SOEs in absolute values are counter-cyclical.

${ }^{30}$ Ideally, we would like to calculate the ratio of loss-making SOEs. However, we do not observe this due to lack of such data at the provincial level for sufficient long time series.

${ }^{31}$ The sample size is smaller in Table 8 compared to other tables. This is because we do not have information on state-sector employment and loss-making enterprises for certain provinces and for certain years.
} 
employment $\left(\triangle S O E_{-} E M P_{i, t}\right)$. We do not find this additional variable to carry any significant explanatory power for the growth rate of local government revenue-the estimated coefficient on $\triangle S O E_{-} E M P_{i, t}$ is negative but insignificant. More importantly, including $\triangle S O E_{-} E M P_{i, t}$ does not affect the estimated revenue cyclicality in Column 1 . In Column 2, we add the first difference of the ratio of loss-making enterprises in total enterprises $\left(\Delta \operatorname{Loss}_{i, t}\right)$, and we find that this variable does not carry any additional explanatory power either. Adding these two variables at the same time (Column 3) does not change the estimated revenue cyclicality. In Columns 4 and 5, we test whether the role of VAT would be affected if we control for the effect of privatization. We did so by repeating the exercises in Columns 3 and 4 in Table 7 while controlling for privatization. In Columns 4 and 5, we continue to find that provinces where VAT is used more intensively experienced a more substantial reduction in the procyclicality of local government revenue.

\subsubsection{Summary}

To summarize, in this section we attempt to explain why local government revenue became less procyclical in China after the 1994 fiscal reform. While the tax-sharing system corrected the procyclical bias in the old central-local fiscal relations, we find that changes of the tax revenue structures due to the increasing importance of the value-added tax also helped reducing the procyclicality of government revenue. In contrast, we do not find any evidence that privatization contributed to the reduced procyclicality of local government revenue.

\subsection{Do intergovernmental transfers help smooth region-specific output fluctuations?}

As we observe from Table 5, intergovernmental transfers in China after 1994 are strongly counter-cyclical with respect to nationwide GDP fluctuations. This means that provinces would receive fewer transfers from the central government if the national economy is in a better state, and vice versa. This finding is in contrast to previous studies on the United States and other OECD countries. However, we do not find strong evidence that intergovernmental transfers in China are counter-cyclical towards province-specific output shocks. The second finding, though, is based on regressions where we treat all provinces as the same. This approach neglects that the extent to which provinces rely on intergovernmental transfers varies significantly across provinces.

As one would expect, poorer provinces rely more on intergovernmental transfers to finance their spending - the ratio of net transfers in total local government spending is on average around 0.57 for poorer provinces and only around 0.36 for richer provinces. Poorer provinces also receive more transfers in the form of earmarked transfers than richer provinces - the average ratio of earmarked transfers in total balance revenue for poorer provinces is 0.39 , compared with 0.20 for richer provinces. 
As earmarked transfers are likely to be more important as a tool of implementing discretionary fiscal policies compared with general purpose transfers, these observations suggest that grants might at least be counter-cyclical with respect to local cycles in poorer provinces.

Could transfers be more counter-cyclical in poorer provinces? To clarify this issue, we estimate the cyclicality of intergovernmental transfers for two groups of provinces based on whether their real GDP per capita in 1994 was above or below the national median in that year. We report the results in Columns 1-2 of Table 8. We control for province-specific trends in these and all subsequent columns in Table 8. Net transfers are strongly counter-cyclical towards nationwide GDP fluctuations in both rich and poor provinces. Interestingly, we find that net transfers are also strongly counter-cyclical with respect to region-specific output fluctuations in poorer provinces, but they remain acyclical in richer provinces.

To investigate the role of earmarked transfers, we conduct two exercises. In Columns 3 , we calculate the average ratio of earmarked transfers in total balance revenue for each province during the period 1996-2009 when the data is available, and then construct a dummy variable Above_Earmarked, which equals 1 if this average ratio in a certain province is above the national median. ${ }^{32}$ We then interact this dummy variable with both local and nationwide output fluctuations. Column 3 indicates that net transfers were only significantly counter-cyclical towards local cycles in provinces which received more earmarked transfers. Interestingly, earmarked transfers do not change the cyclicality of total net transfers towards nationwide cycles. Figure 7 indicates an upward trend in the ratio of earmarked transfers in total balance revenue. As a robustness check, in Column 4 we construct a dummy variable Rank_Earmarked which equals 1 if the ratio of the earmarked transfers in total balance revenue in a certain province is above the national median level in a particular year. This dummy variable therefore may vary across years within a certain province. Consistent with Column 3, we find again that net transfers are counter-cyclical towards local cycles in provinces receiving more earmarked transfers.

Findings in this section suggest that intergovernmental transfers in China, unlike what has been observed in many other countries, are strongly counter-cyclical towards nationwide economic fluctuations. On average, the transfer system does not help smooth regional output shocks. However, we find that net transfers are counter-cyclical in poorer provinces, which rely more heavily on transfers from the central government to finance local spending and receive a higher percentage of transfers in the form of earmarked transfers.

\footnotetext{
32 Similar as in Figure 7, we use data aggregated over the prefectures within each provinces to construct the ratio of earmarked transfers in total balance revenue.
} 


\subsection{Cyclicality of government spending and output volatility}

So far, we have established that government spending, especially at the provincial level, has become significantly less procyclical in China since the 1994 fiscal reform. One interesting issue is whether this change affects the volatility of output. Interestingly, we find that the standard deviation of the growth rate of real output, averaged across provinces, decreased from 0.05 in the pre-1994 period to around 0.02 during the post-1994 period. There are many reasons for the reduced output volatility for a fast growing transitional economy like China, and it is beyond the scope of the current study to investigate all possible explanations. As a rather crude analysis, we investigate the correlation between the cyclicality of government spending and output volatility as follows. We first estimate the cyclicality of government spending towards both local and national cycles for each province during the period 1995-2013, controlling for a linear trend. We label the estimated cyclicality coefficients as $\tilde{\alpha}_{L, i}$ and $\tilde{\alpha}_{N, i}$, respectively. We calculate the standard deviation of the growth rate of real output growth ( $\sigma^{\text {Post } 94}$ ) for each province during the same period. ${ }^{33}$ We then examine the relationship between the cyclicality of provincial government spending and output growth volatility in the spirit of Fetas and Mihov (2006). More specifically, we estimate Equation 5 as follows:

$$
\text { (5) } \ln \left(\sigma_{i}^{\text {Post } 94}\right)=\alpha+\beta_{1} \tilde{\alpha}_{N, i}+\beta_{2} \tilde{\alpha}_{L, i}+\varepsilon_{i}
$$

We report the OLS estimation result based on Equation 5 in Column 1 of Table 9.1. We find a positive and significant correlation between the cyclicality of government spending towards the nationwide output shocks and output volatility at the provincial level. In other words, provinces with more procyclical spending policies also appear to have experienced more volatile growth since the mid-1990s. We do not find any statistically significant association between the cyclicality of government spending towards local shocks and output volatility.

As already discussed, the reduction in the cyclicality of provincial government spending is likely to be associated with both less procyclical revenue due to the introduction of the VAT and a vertical transfer system that was strongly counter-cyclical towards nationwide cycles. In Column 2, we regress $\ln \left(\sigma_{i}^{\text {Post }}{ }^{94}\right)$ on a dummy variable, Above_Ave_VAT, which equals 1 if a province use VAT more intensively (i.e., the share of VAT in total tax revenue, averaged across years, is above the national medium level). Interesting, we find that provinces using VAT more intensively appear to have less volatile output. In Column 3, we regress $\ln \left(\sigma_{i}^{\text {Post } 94}\right)$ on a dummy variable Above_Ave_Transfer that equals 1 if a province relies more on transfers from the central government to finance spending (i.e., the share of transfers in local spending, averaged across years, is above the national medium level).

\footnotetext{
33 Similar to the estimation of the cyclical pattern of spending, we first detrend the output growth data and then calculate the standard deviation of the detrended growth rate.
} 
We find that provinces that rely more on transfers tend to have less volatile output growth. In Column 4, we include both dummies and find that the transfer system has a stronger link to the output volatility. In Column 5, we include $\tilde{\alpha}_{N, i}, \tilde{\alpha}_{L, i}$, and the two dummy variables together as explanatory variables, and we only find a significant and negative association between output volatility and the dummy variable bove_Ave_Transfer, which could be explained if the dummy variable Above_Ave_Transfer absorbs the effect of $\tilde{\alpha}_{N, i}$ on output volatility.

We conduct a rather crude analysis about whether the output growth became less volatile since the mid-1990s is associated with less procyclical government spending. Specifically, we estimate Equation 6 as follows:

$$
(5) \ln \left(\sigma_{i}^{\text {Pre } 94}\right)-\ln \left(\sigma_{i}^{\text {Post } 94}\right)=\alpha+\beta \ln \left(\sigma_{i}^{\text {Pre 94 }}\right)+\gamma_{1} \Delta \tilde{\alpha}_{N, i}+\gamma_{2} \Delta \tilde{\alpha}_{L, i}+\varepsilon_{i}
$$

where $\Delta \tilde{\alpha}_{N, i}=\tilde{\alpha}_{N, i}^{\text {Pre } 94}-\tilde{\alpha}_{N, i}^{\text {Post } 94}$, and $\Delta \tilde{\alpha}_{L, i}=\tilde{\alpha}_{L, i}^{\text {Pre } 94}-\tilde{\alpha}_{L, i}^{\text {Post } 94} \cdot \tilde{\alpha}_{N, i}^{\text {Pre } 94}$ and $\tilde{\alpha}_{L, i}^{\text {Pre } 94}$ are the estimated cyclicality of provincial government spending with respect to nationwide and local cycles during the period 1979-1993. Table 9.2 reports the OLS regression result. Based on this crude analysis, it appears to be the case that provinces that became less procyclical in their fiscal policies since the mid-1990s also experienced more reduction in output volatility. But it is the decline in procyclicality with respect to national, not local cycles which goes along with less local output volatility.

Caution is needed when interpreting results in this section as we do not deal with the endogeneity of the estimated cyclicality of government spending. To establish any causality, we need to use similar instrumental variables approaches as in Fetas and Mihov (2006), which we leave for future research.

\section{Conclusions}

In this paper we have investigated the cyclicality of government spending in China. We start from the observation that public spending in many developing and emerging economies is notoriously procyclical. In fiscal federations, procyclicality of spending is particularly widespread at lower tiers of government. Studying the issue of spending cyclicality in China is interesting because China is both an emerging economy and a country with highly decentralized public spending.

The main finding of our analysis is that provincial government spending in China since the mid-1990s is perhaps an exception to the usual pattern of procyclical fiscal policy found elsewhere. We argue that this is likely a consequence of the 1994 reform of intergovernmental fiscal relations in China. Before this reform provincial government spending was strongly procyclical. This pattern, however, changed after 
the reform. Yet, to graduate from procyclical fiscal policies, much improvement is still needed. While provincial spending in China is countercyclical with regard to nationwide business cycles, it is rather acyclical with respect to local cycles, which implies that it does not offer much insurance against asymmetric economic shocks.

Findings of this paper suggest that the arrangement of intergovernmental fiscal relations could significantly affect the cyclicality of fiscal policies, especially in fiscal federations with decentralized government spending. Moreover, our findings suggest two important ways in which countries may tackle the issue of procyclical public spending at lower levels of government, which is an important matter in any fiscal federation: Firstly, by changing the structure of local tax revenues; and secondly, through a reform of the system of intergovernmental fiscal relations which reduces the dependence of local governments on local tax revenues. Our study provides new perspectives on how developing countries could escape from the "procyclicality trap".

Finally, it is interesting to relate this revenue smoothing property of the value added tax to the debate about the link between tax structures and growth. Previous literature suggests that tax structures matter for long-run economic growth (Arnold et al., 2010). For example, shifting tax revenue from income taxes towards consumption taxes may lead to higher long-run level of GDP per capita, as the latter are likely to be less distortive. Our results suggest a new mechanism through which tax structures would matter for growth. Since procyclical fiscal policies are likely to be harmful to economic growth, increasing the importance of consumption tax in total tax revenue may also benefit long-run growth by reducing the pro-cyclicality of government revenue and consequently, that of government spending. Of course, one may object that the lower cyclicality of the value-added tax reduces the automatic stabilisation properties of the tax system that is the tax burden declines less in economic downturns than in the case of more pro-cyclical tax sources. Which effect is more important - the smoothing of government spending or the reduction in automatic stabilisation on the tax side - is a matter for future research.

\section{References}

Abbott, Andrew, and Jones, Philip. (2012). "Intergovernmental transfers and procyclical public spending,” Economics Letters, Vol. 115, 447-451

Aghion, Philippe and Marinescu, Ioana (2007). "Cyclical Budgetary Policy and Economic Growth: What Do We Learn from OECD Panel Data?” NBER Macroeconomics Annual 22, 251-278

Alesina, Alberto, and Tabellini, Guido (2008). "Why is fiscal policy often procyclical?” CESifo working papers, No. 1556 
Arena, Marco and Revilla, Julio E. (2009). "Pro-cyclical fiscal policy in Brazil: evidence from the states,” World BankPolicy Research Working Paper No. 5144.

Bahl, Roy, and Wallich, Christine (1992). "Intergovernmental fiscal relations in China,” World Bank Working Paper No. 863

Bargain, O., M. Dolls, C. Fuest, D. Neumann, A. Peichl. N. Pestel und S. Siegloch(2013). "Fiscal Union in Europe? Redistributing and Stabilising Effects of a European Tax Benefit System and Fiscal Equalisation Mechanism”, Economic Policy, Vol. 28, 375-422.

Blanchard, Olivier, and Shleifer, Andrei (2000). "Federalism with and without political centralization: China versus Russia,” NBER Working Paper No. 7616, National Bureau of Economic Research, Inc.

Blöchliger, Hansjörg, and Égert, Balázs (2013). "Fiscal consolidation across government levels - Part 3. Intergovernmental grants, pro- or counter-cyclical?” OECD Economics Department Working Papers No. 1072, OECD Publishing

Brandt, Loren, and Zhu, Xiaodong (2000). "Redistribution in a decentralized economy: Growth and inflation in China under reform,” Journal of Political Economy, Vol. 108 (2), 422-439

Clemens, Jeffery, and Miran, Stephen (2012). "Fiscal policy multipliers on subnational government spending," American Economic Journal: Economic Policy, Vol. 4(2), 46-68

Fetas, Anotonio, and Mihov, Ilian (2006). "The macroeconomic effects of fiscal rules in the US states,” Journal of Public Economics, Vol. 90, 101-117

Frankel, Jeffrey A., Vegh, Carlos A., and Vuletin, Guillermo (2013). “On graduation from fiscal procyclicality,” Journal of Development Economics, Vol. 100(1), 32-47

Gavin, Michael and Roberto Perotti (1997). "Fiscal Policy in Latin America,” NBER Macroeconomics Annual, National Bureau of Economic Research, Inc.

Gordon, Roger, and Wei Li (2013). "Provincial and Local Governments in China: Fiscal Institutions and Government Behavior,” Capitalizing China, edited by Joseph Fan and Randall Morck, 337 - 369

Ilzetzki, Ethan, and Vegh, Carlos A. (2008). "Procyclical fiscal Policy in Developing Countries: Truth or Fiction?" NBER Working PapersNo. 14191, National Bureau of Economic Research, Inc. 
Jin, Hehui, Qian, Yingyi, and Weingast, Barry R. (2005). "Regional decentralization and fiscal incentives: Federalism, Chinese style,” Journal of Public Economics, Vol. 89, 1719-1742

Talvi, Ernesto, and Carlos A. Végh (2005). "Tax base variability and pro-cyclical fiscal policy in developing countries," Journal of Development Economics, Vol. 78, 156-190

Lane, Philip R. (2003). "The cyclical behavior of fiscal policy: evidence from the OECD,” Journal of Public Economics, Vol. 87, 2661- 2675

Montinola, Gabriella, Qian, Yingyi, and Weingast, Barry R. (1995). "Federalism, Chinese style: The political basis for economic success,” World Politics, Vol. 48(1), 50-81

Musgrave, Richard M. (1959). The Theory of Public Finance. NY: McGraw-Hill

Oates, Wallace E. (1972). Fiscal Federalism. NY: Harcourt Brace Jovanovich.

Oates, Wallace E. (1999). “An essay on fiscal federalism,” Journal of Economic Literature, Vol. 37, 1120-49

Oi, Jean C. (1992). "Fiscal reform and the economic foundations of local state corporatism in China,” World Politics, Vol. 45(1), 99-126

Pesaran, M. Hashem, and Smith, Ron (1995). "Estimating long-run relationships from dynamic heterogeneous panel,” Journal of Econometrics, Vol. 68(1), 79-113

Pesaran, M. Hashem, Shin, Yongcheol, and Smith, Ron (1999). "Pooled mean group estimation of dynamic heterogeneous panels," Journal of the American Statistical Association, Vol. 94, 289-326

Qian, Yingyi, and Weingast, Barry R. (1997). "Federalism as a commitment to preserving market incentives,” Journal of Economic Perspectives, Vol. 11, 83-92

Rodden, Jonathan, and Wibbels, Eric (2010). "Fiscal decentralization and the business cycle: An empirical study of eight federations,” Economics \& Politics, Vol. 2, 37-67

Roland, G. (1999). Politics, Markets, and Firms: Transition and Economics. MIT Press, Cambridge, MA

Seitz, H. (2000). "Fiscal policy, deficits and politics of subnational governments: thecase of the German Laender,” Public Choice, Vol.102, 183-218 
Sorensen, Bent E., Wu, Lisa, and Yosha, Oved. (2001). "Output fluctuations and fiscal policy: U.S. state and local governments 1978-1994," European Economic Review, Vol. 45, 1271-1310

Wang, Xiao, and Herd, Richard. (2013). "The system of revenue sharing and fiscal transfers in China," OECD Economics Department Working Paper No. 1030, OECD

Wong, C.P.W., Heady, C., and Woo, W.T. (1993). "Economic reform and fiscal management in China: Report of technical assistance project," Asian Development Bank and Ministry of Finance of China

Wong, C.P.W. (2000). "Central-local Relations Revisited: the 1994 Tax Sharing Reform and Public Expenditure Management in China," China Perspectives

Zhang, Yuanyan Sophia Zhang, and Barnett, Steven (2014). "Fiscal vulnerabilities and risks from local government finance in China," International Monetary Fund Working Paper No.14/4

Zhang, and Zou, Hengfu. (1998). "Fiscal decentralization, public spending, and economic growth in China,” Journal of Public Economics, Vol. 67, 221-240 
Table 1: Times series analysis of the cyclicality of government expenditure and revenue with respect to national GDP growth rate: 1978-2013

\begin{tabular}{cccc|ccc}
\hline & \multicolumn{3}{c|}{ Expenditure } & \multicolumn{3}{c}{ Revenue } \\
\hline Period & Total & Central & Local & Total & Central & Local \\
\hline $1978-2013$ & 0.401 & -0.864 & $1.253^{* *}$ & 0.684 & -0.332 & $0.981^{* *}$ \\
& $(0.517)$ & $(0.812)$ & $(0.612)$ & $(0.411)$ & $(0.933)$ & $(0.470)$ \\
$1978-1993$ & 0.770 & -0.365 & $1.679^{*}$ & 0.699 & -0.572 & $1.025^{*}$ \\
& $(0.496)$ & $(0.804)$ & $(0.790)$ & $(0.409)$ & $(1.258)$ & $(0.529)$ \\
$1995-2013$ & -0.823 & $-2.547^{*}$ & -0.176 & 0.695 & 0.545 & $0.898^{* * *}$ \\
& $(0.638)$ & $(1.310)$ & $(0.514)$ & $(0.651)$ & $(1.118)$ & $(0.269)$ \\
\hline
\end{tabular}

Notes: The left-hand side of Table 1 reports the OLS estimate of the coefficient $\alpha$ in the time-series regression $\Delta \ln E X P_{t}=\alpha+\beta \Delta \ln G D P_{t}+\mu_{t}$. The right-hand side of Table 1 reports the OLS estimate of $\beta$ as in $\Delta \ln R E V_{t}=\alpha+\beta \Delta \ln G D P_{t}+\mu_{t}$. Expenditure and revenue figures are in real terms. The year 1994 is excluded from the full sample estimation. Robust standard errors in parentheses. ${ }^{* * *}$ $\mathrm{p}<0.01,{ }^{* *} \mathrm{p}<0.05,{ }^{*} \mathrm{p}<0.1$.

Table 2: Changing cyclicality of government expenditure before and after the 1994 fiscal reform: time-series analysis

\begin{tabular}{|c|c|c|c|c|c|c|}
\hline & \multicolumn{3}{|c|}{ Without other control variables } & \multicolumn{3}{|c|}{ With other control variables } \\
\hline & (1) & (2) & (3) & (4) & (5) & (6) \\
\hline VARIABLES & Total & Central & Local & Total & Central & Local \\
\hline \multirow{2}{*}{$\Delta \ln G D P_{t}$} & 0.770 & -0.365 & $1.679 * *$ & 0.700 & -0.440 & $1.619 * *$ \\
\hline & $(0.492)$ & $(0.797)$ & $(0.783)$ & $(0.448)$ & $(0.829)$ & $(0.748)$ \\
\hline \multicolumn{7}{|l|}{ POST } \\
\hline \multirow[t]{2}{*}{$\times \Delta \ln G D P_{t}$} & $-1.593^{*}$ & -2.182 & $-1.855^{*}$ & $-1.744^{* *}$ & -2.342 & $-2.099 * *$ \\
\hline & $(0.809)$ & $(1.541)$ & $(0.939)$ & $(0.735)$ & $(1.548)$ & $(0.975)$ \\
\hline \multirow[t]{2}{*}{ POST } & $0.241^{* * *}$ & $0.291^{*}$ & $0.256^{* * *}$ & $0.285^{* * *}$ & $0.338 * *$ & $0.322 * * *$ \\
\hline & $(0.079)$ & $(0.147)$ & $(0.091)$ & $(0.073)$ & $(0.158)$ & $(0.106)$ \\
\hline \multirow[t]{2}{*}{$G R \_T O T_{t}$} & & & & 0.086 & 0.090 & 0.185 \\
\hline & & & & $(0.074)$ & $(0.243)$ & $(0.172)$ \\
\hline \multirow[t]{2}{*}{$D E F_{t-1}$} & & & & $-0.038 * * *$ & $-0.041^{*}$ & $-0.047 * * *$ \\
\hline & & & & $(0.008)$ & $(0.022)$ & $(0.017)$ \\
\hline \multirow[t]{2}{*}{ Constant } & -0.035 & 0.035 & -0.099 & -0.007 & 0.065 & -0.073 \\
\hline & $(0.052)$ & $(0.070)$ & $(0.076)$ & $(0.045)$ & $(0.074)$ & $(0.078)$ \\
\hline Observations & 34 & 34 & 34 & 34 & 34 & 34 \\
\hline R-squared & 0.497 & 0.271 & 0.404 & 0.657 & 0.357 & 0.568 \\
\hline
\end{tabular}

Notes: The year 1994 is excluded from the estimation. Robust standard errors in parentheses. *** $\mathrm{p}<0.01, * * \mathrm{p}<0.05,{ }^{*} \mathrm{p}<0.1$. 
Table 3: Cyclicality of provincial government spending: within-groups estimations

\begin{tabular}{|c|c|c|c|c|c|c|c|c|c|}
\hline \multirow{3}{*}{$\Delta \ln E X P_{i, t}$} & \multicolumn{3}{|c|}{ Without trend } & \multicolumn{3}{|c|}{ Common trend } & \multicolumn{3}{|c|}{ Region-specific trend } \\
\hline & (1) & (2) & (3) & (4) & (5) & (6) & (7) & (8) & (9) \\
\hline & $<1994$ & $>1994$ & Full sample & $<1994$ & $>1994$ & Full sample & $<1994$ & $>1994$ & Full sample \\
\hline \multirow{2}{*}[\Delta\operatorname{ln}GSP_{i,t}-\Delta\operatorname{ln}GDP_{t}]{} & $1.558 * * *$ & $0.610^{* * *}$ & $1.540^{* * *}$ & $1.600^{* * *}$ & $0.431^{* *}$ & $1.581 * * *$ & $1.637 * * *$ & 0.015 & $1.591^{* * *}$ \\
\hline & $(0.092)$ & $(0.170)$ & $(0.090)$ & $(0.098)$ & $(0.174)$ & $(0.094)$ & $(0.096)$ & $(0.215)$ & $(0.108)$ \\
\hline \multirow[t]{2}{*}{$\Delta \ln G D P_{t}$} & $1.738^{* * *}$ & -0.003 & $1.728^{* * *}$ & $1.645^{* * *}$ & $-0.415^{* *}$ & $1.634 * * *$ & $1.666^{* * *}$ & $-0.533 * * *$ & $1.640^{* * *}$ \\
\hline & $(0.173)$ & $(0.145)$ & $(0.169)$ & $(0.170)$ & $(0.185)$ & $(0.165)$ & $(0.175)$ & $(0.191)$ & $(0.178)$ \\
\hline \multirow[t]{2}{*}{$P O S T \times\left[\Delta \ln G S P_{i, t}-\Delta \ln G D P_{t}\right]$} & & & $-0.878 * * *$ & & & $-1.080 * * *$ & & & $-1.284 * * *$ \\
\hline & & & $(0.196)$ & & & $(0.210)$ & & & $(0.252)$ \\
\hline \multirow[t]{2}{*}{$P O S T \times \Delta \ln G D P_{t}$} & & & $-1.720^{* * *}$ & & & $-2.029 * * *$ & & & $-2.090 * * *$ \\
\hline & & & $(0.252)$ & & & $(0.282)$ & & & $(0.303)$ \\
\hline \multirow[t]{2}{*}{ POST } & & & $0.248 * * *$ & & & $0.292 * * *$ & & & $0.300 * * *$ \\
\hline & & & $(0.026)$ & & & $(0.029)$ & & & $(0.032)$ \\
\hline Common trend & No & No & No & Yes & Yes & Yes & No & No & No \\
\hline Region-specific trend & No & No & No & No & No & No & Yes & Yes & Yes \\
\hline Observations & 449 & 570 & 1,019 & 449 & 540 & 989 & 449 & 540 & 989 \\
\hline Number of groups & 30 & 30 & 30 & 30 & 30 & 30 & 30 & 30 & 30 \\
\hline R-squared & 0.275 & 0.025 & 0.357 & 0.290 & 0.072 & 0.380 & 0.302 & 0.123 & 0.396 \\
\hline
\end{tabular}

Notes: The year 1994 is excluded from the estimation. Robust clustered standard errors in parentheses. ${ }^{* * *} \mathrm{p}<0.01,{ }^{* *} \mathrm{p}<0.05,{ }^{*} \mathrm{p}<0.1$. 
Table 4: Cyclicality of provincial government revenue: within-groups estimations

\begin{tabular}{|c|c|c|c|c|c|c|c|c|c|}
\hline \multirow{3}{*}{$\Delta \ln R E V_{i, t}$} & \multicolumn{3}{|c|}{ Without trend } & \multicolumn{3}{|c|}{ Common trend } & \multicolumn{3}{|c|}{ Region-specific trend } \\
\hline & (1) & $(2)$ & (3) & (4) & (5) & (6) & $(7)$ & (8) & (9) \\
\hline & $<1994$ & $>1994$ & Full sample & $<1994$ & $>1994$ & Full sample & $<1994$ & $>1994$ & Full sample \\
\hline \multirow[t]{2}{*}[\Delta\operatorname{ln}GSP_{i,t}-\Delta\operatorname{ln}GDP_{t}]{} & $1.433^{* * *}$ & $1.193^{* * *}$ & $1.426 * * *$ & $1.546^{* * *}$ & $1.003^{* * *}$ & $1.531^{* * *}$ & $1.517^{* * *}$ & $0.656^{*}$ & $1.525^{* * *}$ \\
\hline & $(0.113)$ & $(0.208)$ & $(0.112)$ & $(0.116)$ & $(0.200)$ & $(0.111)$ & $(0.129)$ & $(0.347)$ & $(0.138)$ \\
\hline \multirow[t]{2}{*}{$\Delta \ln G D P_{t}$} & $1.935^{* * *}$ & $1.316^{* * *}$ & $1.932 * * *$ & $1.688 * * *$ & $1.164 * * *$ & $1.680 * * *$ & $1.671^{* * *}$ & $1.066^{* * *}$ & $1.677 * * *$ \\
\hline & $(0.219)$ & $(0.173)$ & $(0.222)$ & $(0.197)$ & $(0.173)$ & $(0.200)$ & $(0.208)$ & $(0.208)$ & $(0.209)$ \\
\hline \multirow[t]{2}{*}{$P O S T \times\left[\Delta \ln G S P_{i, t}-\Delta \ln G D P_{t}\right]$} & & & -0.177 & & & $-0.424^{*}$ & & & $-0.798 * *$ \\
\hline & & & $(0.223)$ & & & $(0.215)$ & & & $(0.298)$ \\
\hline \multirow[t]{2}{*}{$P O S T \times \Delta \ln G D P_{t}$} & & & $-0.603^{* *}$ & & & $-0.486 *$ & & & $-0.591^{* *}$ \\
\hline & & & $(0.258)$ & & & $(0.245)$ & & & $(0.277)$ \\
\hline \multirow[t]{2}{*}{ POST } & & & $0.143^{* * *}$ & & & $0.200 * * *$ & & & $0.214^{* * *}$ \\
\hline & & & $(0.026)$ & & & $(0.031)$ & & & $(0.034)$ \\
\hline Common trend & No & No & No & Yes & Yes & Yes & No & No & No \\
\hline Region-specific trend & No & No & No & No & No & No & Yes & Yes & Yes \\
\hline Observations & 449 & 570 & 1,019 & 449 & 540 & 989 & 449 & 540 & 989 \\
\hline Number of groups & 30 & 30 & 30 & 30 & 30 & 30 & 30 & 30 & 30 \\
\hline R-squared & 0.191 & 0.133 & 0.311 & 0.266 & 0.164 & 0.366 & 0.302 & 0.223 & 0.400 \\
\hline
\end{tabular}

Notes: The year 1994 is excluded from the estimation. Robust clustered standard errors in parentheses. ${ }^{* * *} \mathrm{p}<0.01,{ }^{* *} \mathrm{p}<0.05,{ }^{*} \mathrm{p}<0.1$. 
Table 5: Cyclicality of intergovernmental transfers: within-groups estimations

(1) (2) (3)

$\triangle \ln$ TRANSFER $_{i, t} \quad$ Without trend $\quad$ Common trend Region-specific trend

$\begin{array}{lccc}{\left[\Delta \ln G S P_{i, t}-\Delta \ln G D P_{t}\right]} & -0.331 & -0.530 & -0.456 \\ & (0.307) & (0.350) & (0.475) \\ \Delta \ln G D P_{t} & -1.371^{* * *} & -1.597 * * * & -1.564^{* * *} \\ & (0.206) & (0.222) & (0.241) \\ \text { Common trend } & \text { No } & \text { YES } & \text { No } \\ \text { Region-specific trend } & \text { No } & \text { No } & \text { YES } \\ \text { Observations } & 508 & 508 & 508 \\ \text { Number of groups } & 30 & 30 & 30 \\ \text { R-squared } & 0.026 & 0.032 & 0.055 \\ \text { Notes: The sample covers } 1995 \text { onwards. Robust clustered standard errors in parentheses. }{ }^{* * *} \mathrm{p}<0.01, \\ * * \text { p }<0.05, * \text { p }<0.1 .\end{array}$


Table 6: Revenue elasticity: the role of VAT (within-groups estimations)

\begin{tabular}{|c|c|c|c|}
\hline & \multicolumn{2}{|c|}{ 1979-2013 } & \multirow{3}{*}{$\frac{1995-2013}{(3)}$} \\
\hline & (1) & (2) & \\
\hline$\Delta \ln R E V_{i, t}$ & Less VAT & More VAT & \\
\hline$\left[\Delta \ln G S P_{i, t}-\Delta \ln G D P_{t}\right]$ & $\begin{array}{c}1.498 * * * \\
(0.200)\end{array}$ & $\begin{array}{c}1.549 * * * \\
(0.183)\end{array}$ & $\begin{array}{c}1.904 * * \\
(0.839)\end{array}$ \\
\hline$\Delta \ln G D P_{t}$ & $\begin{array}{c}1.706^{* * *} \\
(0.211)\end{array}$ & $\begin{array}{c}1.645^{* * * *} \\
(0.368)\end{array}$ & $\begin{array}{c}3.060 * * * \\
(0.555)\end{array}$ \\
\hline$P O S T \times\left[\Delta \ln G S P_{i, t}-\Delta \ln G D P_{t}\right]$ & $\begin{array}{l}-0.437 \\
(0.375)\end{array}$ & $\begin{array}{c}-1.365 * * * \\
(0.389)\end{array}$ & \\
\hline$P O S T \times \Delta \ln G D P_{t}$ & $\begin{array}{l}-0.187 \\
(0.327)\end{array}$ & $\begin{array}{c}-1.122^{* *} \\
(0.445)\end{array}$ & \\
\hline POST & $\begin{array}{c}0.143 * * * \\
(0.033)\end{array}$ & $\begin{array}{c}0.299 * * * \\
(0.055)\end{array}$ & \\
\hline$A v e_{-} V A T \times\left[\Delta \ln G S P_{i, t}-\Delta \ln G D P_{t}\right]$ & & & $\begin{array}{l}-3.700 \\
(3.784)\end{array}$ \\
\hline$A v e_{-} V A T \times \Delta \ln G D P_{t}$ & & & $\begin{array}{c}-8.672 * * * \\
(2.502)\end{array}$ \\
\hline Constant & $\begin{array}{c}-0.181^{* * *} \\
(0.020)\end{array}$ & $\begin{array}{c}-0.225^{* * *} \\
(0.039)\end{array}$ & $\begin{array}{c}0.007 \\
(0.016)\end{array}$ \\
\hline Region-specific trend & Yes & Yes & Yes \\
\hline Observations & 494 & 495 & 570 \\
\hline R-squared & 0.478 & 0.359 & 0.141 \\
\hline Number of groups & 15 & 15 & 30 \\
\hline $\begin{array}{l}\text { Notes: In Columns } 1 \text { and 2, we split province } \\
\text { tax revenue during } 1995-2013 \text { (Ave_VAT) be } \\
\text { those above it ("More VAT"). In Column 3, } \\
\text { region-specific output fluctuations, and estin } \\
\text { the period 1995-2013. Robust clustered stand }\end{array}$ & $\begin{array}{l}\text { nto two groups } \\
w \text { the correspor } \\
\text { interact the val } \\
\text { e the elasticity } \\
\text { d errors in pare }\end{array}$ & $\begin{array}{l}\text { se with average } \\
\text { national media } \\
\text { Ave_VAT with } \\
\text { evenue with res! } \\
\text { ses. } * * * p<0.01 \text {, }\end{array}$ & $\begin{array}{l}\text { of VAT in total } \\
\text { Less VAT”), and } \\
\text { nationwide and } \\
\text { to output during } \\
<0.05 \text {, }^{*}<0.1 \text {. }\end{array}$ \\
\hline
\end{tabular}


Table 7: Revenue elasticity and privatization: 1979-2013

\begin{tabular}{|c|c|c|c|c|c|}
\hline$\Delta \ln R E V_{i, t}$ & $\begin{array}{c}(1) \\
\text { Full sample } \\
\end{array}$ & $\begin{array}{c}(2) \\
\text { Full sample } \\
\end{array}$ & $\begin{array}{c}\text { (3) } \\
\text { Full sample }\end{array}$ & $\begin{array}{c}(4) \\
\text { Less VAT }\end{array}$ & $\begin{array}{c}(5) \\
\text { More VAT }\end{array}$ \\
\hline$\left[\Delta \ln G S P_{i, t}-\Delta \ln G D P_{t}\right]$ & $\begin{array}{c}1.536^{* * *} \\
(0.129)\end{array}$ & $\begin{array}{c}1.548^{* * *} \\
(0.132)\end{array}$ & $\begin{array}{c}1.540^{* * *} \\
(0.131)\end{array}$ & $\begin{array}{c}1.505^{* * *} \\
(0.175)\end{array}$ & $\begin{array}{c}1.554^{* * *} \\
(0.187)\end{array}$ \\
\hline$\Delta \ln G D P_{t}$ & $\begin{array}{c}1.516^{* * *} \\
(0.218)\end{array}$ & $\begin{array}{c}1.520^{* * *} \\
(0.199)\end{array}$ & $\begin{array}{c}1.494^{* * *} \\
(0.208)\end{array}$ & $\begin{array}{c}1.314^{* * *} \\
(0.161)\end{array}$ & $\begin{array}{c}1.624^{* * *} \\
(0.366)\end{array}$ \\
\hline$P O S T \times\left[\Delta \ln G S P_{i, t}-\Delta \ln G D P_{t}\right]$ & $\begin{array}{c}-1.064^{* * *} \\
(0.274)\end{array}$ & $\begin{array}{c}-1.023^{* * *} \\
(0.273)\end{array}$ & $\begin{array}{c}-1.052^{* * *} \\
(0.266)\end{array}$ & $\begin{array}{l}-0.616^{*} \\
(0.314)\end{array}$ & $\begin{array}{c}-1.571^{* * *} \\
(0.430)\end{array}$ \\
\hline$P O S T \times \Delta \ln G D P_{t}$ & $\begin{array}{l}-0.229 \\
(0.310)\end{array}$ & $\begin{array}{l}-0.265 \\
(0.291)\end{array}$ & $\begin{array}{l}-0.223 \\
(0.309)\end{array}$ & $\begin{array}{c}0.418 \\
(0.359)\end{array}$ & $\begin{array}{l}-0.932 * \\
(0.465)\end{array}$ \\
\hline POST & $\begin{array}{c}0.191^{* * *} \\
(0.041)\end{array}$ & $\begin{array}{c}0.201^{* * *} \\
(0.037)\end{array}$ & $\begin{array}{c}0.192^{* * *} \\
(0.041)\end{array}$ & $\begin{array}{l}0.090^{*} \\
(0.044)\end{array}$ & $\begin{array}{c}0.292^{* * *} \\
(0.060)\end{array}$ \\
\hline$\triangle S O E_{-} E M P_{i, t}$ & $\begin{array}{l}-0.113 \\
(0.167)\end{array}$ & & $\begin{array}{l}-0.118 \\
(0.169)\end{array}$ & $\begin{array}{l}-0.262 \\
(0.285)\end{array}$ & $\begin{array}{l}-0.027 \\
(0.172)\end{array}$ \\
\hline$\Delta \operatorname{Loss}_{i, t}$ & & $\begin{array}{l}-0.044 \\
(0.084)\end{array}$ & $\begin{array}{l}-0.052 \\
(0.088)\end{array}$ & $\begin{array}{l}-0.102 \\
(0.186)\end{array}$ & $\begin{array}{l}-0.048 \\
(0.097)\end{array}$ \\
\hline Constant & $\begin{array}{c}-0.195^{* * *} \\
(0.024)\end{array}$ & $\begin{array}{c}-0.196^{* * *} \\
(0.022)\end{array}$ & $\begin{array}{c}-0.193^{* * *} \\
(0.023)\end{array}$ & $\begin{array}{c}-0.151^{* * *} \\
(0.019)\end{array}$ & $\begin{array}{c}-0.224^{* * *} \\
(0.039)\end{array}$ \\
\hline Region-specific trend & Yes & Yes & Yes & Yes & Yes \\
\hline Observations & 910 & 910 & 910 & 441 & 469 \\
\hline R-squared & 0.400 & 0.400 & 0.401 & 0.522 & 0.349 \\
\hline Number of groups & 30 & 30 & 30 & 15 & 15 \\
\hline
\end{tabular}

Notes: Robust clustered standard errors in parentheses. ${ }^{* * *} \mathrm{p}<0.01,{ }^{* *} \mathrm{p}<0.05,{ }^{*} \mathrm{p}<0.1$. 
Table 8: Are transfers more counter-cyclical in some provinces than others?

(1) (2)

$\Delta \ln T R A N S F E R_{i, t}$

High GDP per capita Low GDP per capita

Full sample

Full sample

$\left[\Delta \ln G S P_{i, t}-\Delta \ln G D P_{t}\right]$

0.855

$-1.273^{*}$

0.962

0.622

(0.644)

(0.595)

(0.727)

(0.547)

$\Delta \ln G D P_{t}$

$-1.422 * * *$

$-1.684 * * *$

$-3.286 * * *$

$-3.423 * * *$

(0.370)

(0.307)

(0.476)

(0.538)

Above_Earmarked

$\times\left[\Delta \ln G S P_{i, t}-\Delta \ln G D P_{t}\right]$

$-2.314 * *$

(0.952)

Rank_Earmarked

$\times\left[\Delta \ln G S P_{i, t}-\Delta \ln G D P_{t}\right]$

$-1.501^{* *}$

(0.614)

Above_Earmarked

$\times \Delta \ln G D P_{t}$

0.312

(0.699)

Rank_Earmarked

$\times \Delta \ln G D P_{t}$

$\Delta$ Earmarked

0.140*

(0.077)

Rank_Earmarked

0.040

(0.095)

Region-specific trend

Yes

Yes

Yes

Yes

Province FE

Yes

Yes

Yes

Yes

Observations

253

255

414

414

No. of groups

15

15

30

30

Notes: In Columns 1 and 2, we split the provinces into two groups: those with per capita GDP in 1994 above the national median ("High GDP per capita"), and those below the national median ("Low GDP per capita”). In Columns 3, we calculate the average ratio of earmarked transfers in total balance revenue for each province and construct the dummy variable Above_Earmarked, which equals 1 if the average ratio in a certain province is above the national median. In Column 4, we construct the dummy variable Rank_Earmarked which equals 1 if the ratio of the earmarked transfers in total balance revenue in a certain province is above the national median level in a particular year. Robust clustered standard errors in parentheses. ${ }^{* * *} \mathrm{p}<0.01,{ }^{* *} \mathrm{p}<0.05,{ }^{*} \mathrm{p}<0.1$. 
Table 9.1: Cyclicality of government spending and output volatility post 1994

Dep. Variable:

\begin{tabular}{|c|c|c|c|c|c|}
\hline $\ln \left(\sigma^{\text {Post } 94}\right)$ & $(1)$ & $(2)$ & (3) & (4) & (5) \\
\hline \multirow[t]{2}{*}{$\tilde{\alpha}_{N, i}$} & $0.136 * *$ & & & & 0.058 \\
\hline & $(0.049)$ & & & & $(0.060)$ \\
\hline \multirow[t]{2}{*}{$\tilde{\alpha}_{L, i}$} & -0.046 & & & & -0.007 \\
\hline & $(0.042)$ & & & & $(0.043)$ \\
\hline \multirow[t]{2}{*}{$A b o v e_{-} A v e_{-} V A T$} & & $-0.222 * *$ & & -0.168 & -0.144 \\
\hline & & $(0.108)$ & & $(0.106)$ & $(0.113)$ \\
\hline \multirow[t]{2}{*}{ Above_Ave_Transfer } & & & $-0.302 * * *$ & $-0.268 * *$ & $-0.181^{*}$ \\
\hline & & & $(0.100)$ & $(0.106)$ & $(0.103)$ \\
\hline Observations & 30 & 30 & 30 & 30 & 30 \\
\hline R-squared & 0.259 & 0.132 & 0.244 & 0.317 & 0.356 \\
\hline
\end{tabular}

Table 9.2: Changes of government spending cyclicality and changes of output volatility

Dep. Variable:

$\ln \left(\sigma^{\text {Pre } 94}\right)-\ln \left(\sigma^{\text {Post } 94}\right)$

$\ln \left(\sigma^{\text {Pre } 94}\right)$

$0.888 * * *$

$\Delta \tilde{\alpha}_{N, i}$

$(0.236)$

$0.077 * *$

$\Delta \tilde{\alpha}_{L, i}$

$-0.028$

(0.034)

Observations

R-squared

0.379

Notes: Robust standard errors in parentheses. ${ }^{* * *} \mathrm{p}<0.01$, ${ }^{* *} \mathrm{p}<0.05,{ }^{*} \mathrm{p}<0.1$. 


\section{Appendices A-D}

Appendix A: Tax revenue sharing between central and local government (China Statistical Yearbook)

\begin{tabular}{|c|c|c|c|c|}
\hline & \multicolumn{2}{|c|}{ Sharing rules $(\%)$} & \multicolumn{2}{|c|}{ \% Total tax revenue 2012} \\
\hline & Central & Local & Central & Local \\
\hline \multicolumn{5}{|l|}{ Central taxes } \\
\hline Consumption tax & 100 & 0 & 14.77 & \\
\hline Tariffs & 100 & 0 & 5.22 & \\
\hline $\begin{array}{l}\text { Intl trade-related consumption tax and } \\
\text { VAT }\end{array}$ & 100 & 0 & 27.77 & \\
\hline Refunds of VAT and consumption tax & 100 & 0 & -19.57 & \\
\hline Vehicle purchase tax & 100 & 0 & 4.18 & \\
\hline Cargo tax & 100 & 0 & 0.07 & \\
\hline \multicolumn{5}{|l|}{ Shared taxes } \\
\hline VAT & 75 & 25 & 36.9 & 14.24 \\
\hline Corporate income tax & 60 & 40 & 22.67 & 16.00 \\
\hline Personal income tax & 60 & 40 & 6.55 & 4.92 \\
\hline Stamp tax on securities & 97 & 3 & 5.52 & 0.02 \\
\hline \multicolumn{5}{|l|}{ Sub-national taxes } \\
\hline Business tax & 1 & 99 & 0.38 & 32.85 \\
\hline Resource tax & 0 & 100 & & 1.81 \\
\hline Urban maintenance and development tax & 0 & 100 & 0.36 & 6.20 \\
\hline House property tax & 0 & 100 & & 2.90 \\
\hline Urban land use tax & 0 & 100 & & 3.26 \\
\hline Land appreciation tax & 0 & 100 & & 5.75 \\
\hline Tax on vehicles and boat operation & 0 & 100 & & 0.83 \\
\hline Tax on the use of arable land & 0 & 100 & & 3.43 \\
\hline Tobacco tax & 0 & 100 & & 0.28 \\
\hline Tax on deeds & 0 & 100 & & 6.07 \\
\hline
\end{tabular}




\section{Appendix B: Variable definitions and data sources}

Ave_VAT: the ratio of the value-added tax revenue in total tax revenue, averaged across the post-1994 period (Zhongguo caizheng tongji nianjian)

DEF: Total government deficit, defined as (Total government expenditure-Total government revenue)/GDP (China Statistical Yearbook)

EXP: Real government spending. The nominal data is obtained from the Zhongguo caizheng tongji nianjian. The nominal data is the transformed into real one using province-specific deflators

GDP: Real gross domestic product (China Statistical Yearbook). To transform the nominal GDP into real GDP, we use the GDP deflator provided by the World Bank

GR_TOT: the growth rate of trade openness, which is defined as the sum of exports and imports divided by GDP (China Statistical Yearbook)

GSP: Real provincial output (China Statistical Yearbook). To transform the nominal output into real ones, we use province-specific deflators

Loss: the ratio of loss-making enterprises in total enterprises (China Statistical Yearbook)

REV: Real government tax revenue (Zhongguo caizheng tongji nianjian)

SOE_EMP: the ratio of SOEs' employment in total employment (China Statistical Yearbook)

TRANSFER: Real net transfers the local governments receive from the central government. It is defined as transfers from central government minus transfers to central government (Zhongguo caizheng tongji nianjian)

POST: a dummy variable that equals 1 for the period 1995-2013, and 0 before 1994 
Appendix C: Time-series properties of key variables

\begin{tabular}{|c|c|c|c|c|}
\hline & \multicolumn{2}{|l|}{$<1994$} & \multicolumn{2}{|l|}{$>1994$} \\
\hline & Without T & With T & Without T & With T \\
\hline \multicolumn{5}{|l|}{ In levels } \\
\hline $\ln E X P$ & 1.000 & 0.970 & 0.988 & 0.009 \\
\hline $\ln R E V$ & 1.000 & 0.023 & 1.000 & 0.458 \\
\hline $\ln T R A N S F E R$ & & & 1.000 & 0.001 \\
\hline \multicolumn{5}{|l|}{ First difference } \\
\hline$\Delta \ln E X P$ & 0.000 & 0.001 & 0.000 & 0.000 \\
\hline$\Delta \ln R E V$ & 0.000 & 0.000 & 0.000 & 0.000 \\
\hline$\triangle \ln T R A N S F E R$ & & & 0.000 & 0.000 \\
\hline
\end{tabular}

Notes: This table presents p-values from the Fisher-type test for unit roots in heterogeneous panels (Maddala and $\mathrm{Wu}, 1999$ ). Suppose the stochastic process, $y_{i, t}$, is generated by an autoregressive process:

$$
\Delta y_{i, t}=\alpha_{i}+\beta_{i} y_{i, t-1}+\delta_{i} t+\sum_{j=1}^{p} \gamma_{i, j} \Delta y_{i, t}+\varepsilon_{i, t}
$$

where $\mathrm{t}$ is a linear trend. The null hypothesis is $H_{0}: \beta_{i}=0$ for for $i$, and the alternative is $H_{1}: \beta_{i}<$ $0, i=1,2, \ldots N_{1}, \beta_{i}=0, i=N_{1}+1, N_{1}+2, \ldots N, 0<\lim _{N \rightarrow \infty}\left(N_{1} / N\right) \leq 1$. TheFisher test first computes the p-value $\pi_{i}$ for each group using the Phillips-Perron unit-root test. Then it computes the statistic $-2 \sum \log \pi_{i}$, which follows a $\chi^{2}$ distribution with $2 \mathrm{~N}$ degrees of freedom under the null. We report the $\mathrm{p}$-values of the $\chi^{2}$ statistics in this table. Results are reported for the lag length $\mathrm{p}=1$, but are not highly sensitive to this choice. These tests are computed using the command $x t f i s h e r$ in Stata. 
Appendix D: Robustness checks of benchmark results using the Pooled Mean-group and Mean-group estimations

Table D.1: Short-term and long-term expenditure elasticities: OLS, pooled mean-group (PMG) and unweighted mean-group (MG) estimations

\begin{tabular}{|c|c|c|c|c|c|c|}
\hline & \multicolumn{2}{|c|}{ OLS } & \multicolumn{2}{|c|}{ PMG } & \multicolumn{2}{|c|}{ MG } \\
\hline & (1) & (2) & (3) & (4) & (5) & (6) \\
\hline$\Delta \ln E X P_{i, t}$ & $<1994$ & $>1994$ & $<1994$ & $>1994$ & $<1994$ & $>1994$ \\
\hline \multicolumn{7}{|l|}{ Convergence speed } \\
\hline $\ln E X P_{i, t-1}$ & $\begin{array}{c}-0.613^{* * *} \\
(0.020)\end{array}$ & $\begin{array}{c}-0.438^{* * *} \\
(0.039)\end{array}$ & $\begin{array}{c}-0.659 * * * \\
(0.031)\end{array}$ & $\begin{array}{c}-0.486^{* * *} \\
(0.040)\end{array}$ & $\begin{array}{c}-0.709 * * * \\
(0.042)\end{array}$ & $\begin{array}{c}-0.614^{* * *} \\
(0.049) \\
\end{array}$ \\
\hline \multicolumn{7}{|l|}{ SR coefficients } \\
\hline$\left[\Delta \ln G S P_{i, t}-\Delta \ln G D P_{t}\right]$ & $\begin{array}{c}1.378^{* * *} \\
(0.145)\end{array}$ & $\begin{array}{c}0.230 \\
(0.179)\end{array}$ & $\begin{array}{c}1.926 * * * \\
(0.142)\end{array}$ & $\begin{array}{c}-0.544^{* *} \\
(0.250)\end{array}$ & $\begin{array}{c}2.032 * * * \\
(0.248)\end{array}$ & $\begin{array}{c}-1.148^{* * *} \\
(0.362)\end{array}$ \\
\hline$\Delta \ln G D P_{t}$ & $\begin{array}{c}1.569 * * * \\
(0.169)\end{array}$ & $\begin{array}{c}-0.720^{* * *} \\
(0.222)\end{array}$ & $\begin{array}{c}1.994 * * * \\
(0.217)\end{array}$ & $\begin{array}{c}-1.045^{* * *} \\
(0.266)\end{array}$ & $\begin{array}{c}2.300 * * * \\
(0.339)\end{array}$ & $\begin{array}{c}-1.385^{* * *} \\
(0.348)\end{array}$ \\
\hline \multicolumn{7}{|l|}{ LR coefficients } \\
\hline$[\ln G S P-\ln G D P \quad]$ & $\begin{array}{c}1.426^{* * *} \\
(0.260)\end{array}$ & $\begin{array}{c}0.262 \\
(0.348)\end{array}$ & $\begin{array}{c}1.959 * * * \\
(0.222)\end{array}$ & $\begin{array}{c}-0.315^{* *} \\
(0.160)\end{array}$ & $\begin{array}{c}2.417 * * * \\
(0.553)\end{array}$ & $\begin{array}{c}-0.884^{* *} \\
(0.411)\end{array}$ \\
\hline $\ln G D P$ & $\begin{array}{c}2.880 * * * \\
(0.245)\end{array}$ & $\begin{array}{c}0.738 * * \\
(0.272)\end{array}$ & $\begin{array}{c}2.487 * * * \\
(0.176)\end{array}$ & $\begin{array}{c}0.959 * * * \\
(0.129)\end{array}$ & $\begin{array}{c}2.778 * * * \\
(0.424)\end{array}$ & $\begin{array}{c}1.294^{* * *} \\
(0.309)\end{array}$ \\
\hline Region-specific trend & yes & yes & yes & yes & yes & yes \\
\hline Observations & 449 & 540 & 449 & 540 & 449 & 540 \\
\hline Number of groups & 30 & 30 & 30 & 30 & 30 & 30 \\
\hline
\end{tabular}

Notes: We report the OLS, Pooled Mean-group (PMG) and the unweighted Mean-group (MG) estimation results based on Equation 4. Robust clustered standard errors in parentheses. ${ }^{* * *} \mathrm{p}<0.01$, ** $\mathrm{p}<0.05,{ }^{*} \mathrm{p}<0.1$. 
Table D.2: Short-term and long-term revenue elasticity: OLS, Pooled mean-group and mean-group estimations

\begin{tabular}{lcccccc}
\multicolumn{2}{c}{ OLS } & \multicolumn{2}{c}{ PMG } & \multicolumn{2}{c}{ MG } \\
\hline $\ln R E V_{i, t}$ & $(1)$ & $(2)$ & $(3)$ & $(4)$ & $(5)$ & $(6)$ \\
\hline Convergence speed & $<1994$ & $>1994$ & $<1994$ & $>1994$ & $<1994$ & $>1994$ \\
$\ln R E V_{i, t-1}$ & $-0.540^{* * *}$ & $-0.335^{* * *}$ & $-0.625^{* * *}$ & $-0.520^{* * *}$ & $-0.751^{* * *}$ & $-0.692^{* * *}$ \\
& $(0.044)$ & $(0.055)$ & $(0.051)$ & $(0.069)$ & $(0.061)$ & $(0.061)$ \\
\hline SR coefficients & & & & & & \\
{$\left[\Delta \ln G S P_{i, t}-\Delta \ln G D P_{t}\right]$} & $1.463^{* * *}$ & $0.831^{* * *}$ & $1.930^{* * *}$ & 0.482 & $1.799 * * *$ & -0.061 \\
& $(0.151)$ & $(0.272)$ & $(0.215)$ & $(0.320)$ & $(0.359)$ & $(0.424)$ \\
$\Delta \ln G D P_{t}$ & $1.495^{* * *}$ & $0.973^{* * *}$ & $1.808^{* * *}$ & $0.713^{* * *}$ & $2.017^{* * *}$ & 0.475 \\
& $(0.200)$ & $(0.215)$ & $(0.260)$ & $(0.236)$ & $(0.386)$ & $(0.314)$ \\
\hline LR coefficients & & & & & \\
{$[\ln G S P \quad-\ln G D P$} & $1.774^{* * *}$ & $2.249 * * *$ & $1.808^{* * *}$ & $2.215^{* * *}$ & $2.175^{* * *}$ & $1.787 * * *$ \\
& $(0.353)$ & $(0.394)$ & $(0.157)$ & $(0.126)$ & $(0.636)$ & $(0.570)$ \\
$\ln G D P$ & $2.118^{* * *}$ & $2.590^{* * *}$ & $1.417 * * *$ & $1.798^{* * *}$ & $2.092^{* * *}$ & $2.510^{* * *}$ \\
& $(0.303)$ & $(0.411)$ & $(0.128)$ & $(0.113)$ & $(0.450)$ & $(0.667)$ \\
\hline Region-specific trend & yes & yes & yes & yes & yes & yes \\
Observations & 449 & 540 & 449 & 540 & 449 & 540 \\
Number of groups & 30 & 30 & 30 & 30 & 30 & 30 \\
\hline
\end{tabular}

Notes: We report the OLS, Pooled Mean-group (PMG) and the unweighted Mean-group (MG) estimation results based on Equation 4. Robust clustered standard errors in parentheses. *** $\mathrm{p}<0.01$, ** $\mathrm{p}<0.05,{ }^{*} \mathrm{p}<0.1$. 
Table D.3: Short-term and long-term elasticity of net transfers: OLS, Pooled mean-group and mean-group estimations

\begin{tabular}{|c|c|c|c|}
\hline & (1) & (3) & (5) \\
\hline$\Delta \ln T R A N S F E R_{i, t}$ & OLS & PMG & MG \\
\hline \multicolumn{4}{|l|}{ Convergence speed } \\
\hline $\ln T R A N S F E R_{i, t-1}$ & $\begin{array}{c}-0.643 * * * \\
(0.048)\end{array}$ & $\begin{array}{c}-0.751^{* * * *} \\
(0.052)\end{array}$ & $\begin{array}{c}-0.877^{* * *} \\
(0.057)\end{array}$ \\
\hline \multicolumn{4}{|l|}{ SR coefficients } \\
\hline$\left[\Delta \ln G S P_{i, t}-\Delta \ln G D P_{t}\right]$ & $\begin{array}{c}-0.179 \\
(0.479)\end{array}$ & $\begin{array}{l}-0.563 \\
(0.817)\end{array}$ & $\begin{array}{l}-1.437 \\
(0.978)\end{array}$ \\
\hline$\Delta \ln G D P_{t}$ & $\begin{array}{c}-2.089 * * * \\
(0.238) \\
\end{array}$ & $\begin{array}{c}-2.654 * * * \\
(0.362) \\
\end{array}$ & $\begin{array}{c}-2.973^{* * *} \\
(0.578)\end{array}$ \\
\hline \multicolumn{4}{|l|}{ LR coefficients } \\
\hline$[\ln G S P-\ln G D P \quad]$ & $\begin{array}{c}-1.357 * * * \\
(0.338)\end{array}$ & $\begin{array}{c}-1.713^{* * *} \\
(0.220)\end{array}$ & $\begin{array}{c}-2.979 * * * \\
(0.491)\end{array}$ \\
\hline $\ln G D P$ & $\begin{array}{c}-1.478 * * * \\
(0.286)\end{array}$ & $\begin{array}{c}-0.916^{* * *} \\
(0.172) \\
\end{array}$ & $\begin{array}{l}-0.708 * \\
(0.392)\end{array}$ \\
\hline Region-specific trend & yes & yes & yes \\
\hline Observations & 508 & 508 & 508 \\
\hline Number of groups & 30 & 30 & 30 \\
\hline
\end{tabular}

